\title{
Research Evidence on High-Fat Diet-Induced Prostate Cancer Development and Progression
}

\author{
Shintaro Narita *(D), Taketoshi Nara, Hiromi Sato, Atsushi Koizumi, Mingguo Huang, \\ Takamitsu Inoue and Tomonori Habuchi \\ Department of Urology, Akita University School of Medicine, Akita 010-8543, Japan; \\ bkspt512@yahoo.co.jp (T.N.); hiromisato2002@yahoo.co.jp (H.S.); koizu3atsu4@yahoo.co.jp (A.K.); \\ huangmg0319@yahoo.co.jp (M.H.); takmitz@gmail.com (T.I.); thabuchi@gmail.com (T.H.) \\ * Correspondence: naritashintaro@gmail.com; Tel.: +81-18-884-6154
}

Received: 22 March 2019; Accepted: 29 April 2019; Published: 30 April 2019

check for updates

\begin{abstract}
Although recent evidence has suggested that a high-fat diet (HFD) plays an important role in prostate carcinogenesis, the underlying mechanisms have largely remained unknown. This review thus summarizes previous preclinical studies that have used prostate cancer cells and animal models to assess the impact of dietary fat on prostate cancer development and progression. Large variations in the previous studies were found during the selection of preclinical models and types of dietary intervention. Subcutaneous human prostate cancer cell xenografts, such as LNCaP, LAPC-4, and PC-3 and genetic engineered mouse models, such as TRAMP and Pten knockout, were frequently used. The dietary interventions had not been standardized, and distinct variations in the phenotype were observed in different studies using distinct HFD components. The use of different dietary components in the research models is reported to influence the effect of diet-induced metabolic disorders. The proposed underlying mechanisms for HFD-induced prostate cancer were divided into (1) growth factor signaling, (2) lipid metabolism, (3) inflammation, (4) hormonal modulation, and others. A number of preclinical studies proposed that dietary fat and/or obesity enhanced prostate cancer development and progression. However, the relationship still remains controversial, and care should be taken when interpreting the results in a human context. Future studies using more sophisticated preclinical models are imperative in order to explore deeper understanding regarding the impact of dietary fat on the development and progression of prostate cancer.
\end{abstract}

Keywords: animal model; diet; fat; in vitro; in vivo; mouse; prostate cancer

\section{Introduction}

Prostate cancer is the most common type of cancer among men in 92 countries and the leading cause of cancer deaths among men in 48 countries [1]. In the United States as well, prostate cancer has been the most commonly diagnosed type of cancer among men, accounting for almost 1 in 5 new diagnoses [2]. While the incidence of latent prostate cancer has been similar between the United States and Japan, the incidence of clinically detected prostate cancer has been lower in Asia, including Japan [3,4]. Of note, the incidence of prostate cancer in Chinese and Japanese men has been reported to increase substantially after migration to the United States [5]. Furthermore, the morbidity and mortality due to prostate cancer in Asia increased remarkably in recent years [6]. Although the etiology of prostate cancer is multifocal, these epidemiological findings, including geographic and ethnic differences, suggest that lifestyle and/or environmental factors have a substantial influence on the development and progression of prostate cancer [7]. Epidemiological evidence suggested that among the acquired risk factors for prostate cancer development and progression, diet and obesity have a potential to cause prostate cancer initiation, promotion, and progression [8,9]. Several studies have 
implicated dietary fats as important factors of prostate cancer risk and its aggressive phenotype $[9,10]$. A number of clinical and preclinical studies have shown that total fat intake and specific fat composition play a potential role in prostate cancer, although their findings have remained inconclusive.

Considering these backgrounds, this study aimed to summarize previous preclinical studies regarding the relationship between dietary fat and prostate cancer development and progression, focusing on differences in preclinical models and dietary fat composition. Furthermore, potential mechanisms on dietary fat-induced prostate carcinogenesis were discussed by updating previous research evidence. To this end, previous preclinical studies investigating dietary fat and prostate cancer were identified using a PubMed search including only studies published in English. This review helps us to understand the current state of diet-induced prostate cancer research in order to guide future works exploring the association between dietary-fat and prostate cancer.

\section{Various Preclinical Models}

A number of animal models, including those involving prostate cancer cell xenografts and allografts, Transgenic Adenocarcinoma of the Mouse Prostate (TRAMP) mice, and other genetically engineered mice targeting oncogenes and tumor suppressor genes, were tested in order to assess the impact of dietary-fat intake on prostate cancer development and progression (Table 1). First, the models used in the previous studies were summarized as follows. 
Table 1. Summary of preclinical models on dietary-fat induced prostate cancer development and progression.

\begin{tabular}{|c|c|c|c|c|c|c|}
\hline Authors & Years & Animal Models & Tumors & Diet Summary & End Point & Summary of the Results \\
\hline Wang [11] & 1995 & Nude mice & LNCaP & $\begin{array}{c}40.5 \%, 30.8 \%, 21.2 \%, 11.6 \% \text {, or } \\
2.31 \% \text { fat }\end{array}$ & $\begin{array}{l}\text { Tumor growth rates, } \\
\text { tumor weights, ratios of } \\
\text { final tumor weights to } \\
\text { animal weights, PSA }\end{array}$ & $\begin{array}{l}\text { Groups that continued to receive a } 40.51 \% \text { fat diet were substantially } \\
\text { greater tumor growth rates, final tumor weights, and ratios of final } \\
\text { tumor weights to animal weights than those whose diets were } \\
\text { changed to } 2.3 \mathrm{kcal} \%, 11.6 \mathrm{kcal} \% \text {, or } 21.2 \mathrm{kcal} \% \text { fat. }\end{array}$ \\
\hline Connoly [12] & 1997 & Nude mice & $\begin{array}{l}\text { a) DU145 } \\
\text { subcutaneous } \\
\text { xenograft, b) DU145 } \\
\text { into prostate }\end{array}$ & $\begin{array}{l}\text { a) } 18: 2 \omega \text {-6-rich vs. } 18: 3 \\
\omega-3 \text {-rich vs. } 20: 5 \text { and } 22: 6 \\
\omega \text {-3-rich, b) } \omega \text {-6-rich vs. a LF }\end{array}$ & Tumor growth & $\begin{array}{l}\text { a) } 18: 2 \omega \text {-6-rich vs. } 18: 3 \omega \text {-3-rich mice were similar; a } 30 \% \text { reduction in } \\
\text { tumor growth was observed in the 20:5 and } 22: 6 \omega \text {-3-rich groups. b) } \\
\text { The mean tumor weight in the } \omega-6 \text {-rich group was twice that in the } \\
\text { low-fat group. }\end{array}$ \\
\hline Ngo [13] & 2002 & & $\begin{array}{l}\text { LNCaP cultured with } \\
\text { human serum }\end{array}$ & $\begin{array}{l}\text { Before and after residential diet } \\
\text { and exercise }\end{array}$ & $\begin{array}{l}\text { Cell growth, apoptosis, } \\
\text { necrosis }\end{array}$ & $\begin{array}{l}\text { Serum-stimulated LNCaP cell growth was reduced by } 30 \% \text { in } \\
\text { post-11-day serum and by } 44 \% \text { in long-term serum relative to baseline } \\
\text { LNCaP cells incubated with post-diet and exercise serum showed } \\
\text { higher apoptosis/necrosis, compared to baseline. }\end{array}$ \\
\hline Barnard [14] & 2003 & & $\begin{array}{l}\text { LNCaP cultured with } \\
\text { human serum }\end{array}$ & $\begin{array}{l}\text { Volunteer serum (control, LF } \\
\text { and exercise, exercise alone) }\end{array}$ & Cell growth & $\begin{array}{l}\text { Both the LF/exercise and exercise alone groups had reduced LNCaP } \\
\text { cell growth compared to control. }\end{array}$ \\
\hline Ngo [15] & 2003 & CB17 SCID & $\begin{array}{l}\text { a) LAPC-4 xenograft, } \\
\text { b) LAPC- } 4 \text { culture } \\
\text { with } 10 \% \text { mouse } \\
\text { serum }\end{array}$ & $\operatorname{HFD}(42 \%)$ vs. LFD $(12 \%)$ & $\begin{array}{l}\text { a) tumor growth, PSA, b) } \\
\text { cell growth }\end{array}$ & $\begin{array}{l}\text { LFD mice had significantly slower tumor growth rates and lower } \\
\text { serum PSA levels compared to HFD mice. LAPC-4 cells cultured } \\
\text { in vitro with media containing serum from LFD mice demonstrated } \\
\text { slower growth than LAPC-4 cells cultured in media containing HFD } \\
\text { mice serum. }\end{array}$ \\
\hline Ngo [16] & 2004 & CB17 SCID & LAPC-4 xeograft & HFD $(42 \%)$ vs LFD $(12 \%)$ & Tumor growth, survival & $\begin{array}{l}\text { Tumor latency and mouse survival were significantly longer in the } \\
\text { LFD castration versus HFD castration group. }\end{array}$ \\
\hline $\begin{array}{c}\text { Venkateswaran } \\
{[17]}\end{array}$ & 2007 & Swiss nu/nu & LNCaP xenograft & HC + HFD vs. LC + HFD & Tumor growth & Mice on the HC-HFD diet experienced increased tumor growth. \\
\hline Berquin [18] & 2007 & $\begin{array}{l}\text { Prostate-specific Pten } \\
\text { deletion mouse }\end{array}$ & & High $\omega-6$ vs. $\omega-3$ diet & $\begin{array}{l}\text { Prostate weight, rate of } \\
\text { invasive carcinoma }\end{array}$ & $\begin{array}{l}\text { Prostate weight was significantly lower in mice fed high } \omega-3 \text {; half of } \\
\text { the mice fed } \omega-3 \text { develop invasive carcinoma, whereas } 80 \% \text { of the } \\
\text { mice fed high } \omega-6 \text { diet had invasive carcinoma. }\end{array}$ \\
\hline Kobayashi [19] & 2008 & $\begin{array}{l}\text { Prostate specific } \\
\text { High-Myc transgenic } \\
\text { mouse }\end{array}$ & $\begin{array}{l}\text { a)LNCaP, b)MycCap } \\
\text { with mice serum }\end{array}$ & HFD $(42 \%)$ vs LFD $(12 \%)$ & $\begin{array}{l}\text { Rate of mPIN and cancer } \\
\text { incidence }\end{array}$ & $\begin{array}{c}\text { The number of mice that developed invasive adenocarcinoma at } 7 \\
\text { months was } 27 \% \text { less in the LFD group (12/28) compared to the HFD } \\
\text { group }(23 / 33, p=0.04) \text {. Epithelial cells in PIN lesions in the LFD group } \\
\text { had a significantly lower proliferative index compared to epithelial } \\
\text { cells in the HFD group ( } 21.7 \% \text { vs. } 28.9 \%, p<0.05) \text {. }\end{array}$ \\
\hline Freedland [20] & 2008 & SCID & LAPC-4 xenograft & $\begin{array}{l}\text { NCKD ( } 84 \% \text { fat) vs. LFD }(12 \% \\
\text { fat) vs. WD ( } 40 \% \text { fat })\end{array}$ & Tumor growth, survival & $\begin{array}{l}\text { NCKD mice tumor volumes were } 33 \% \text { smaller than WD mice } \\
\text { (rank-sum, } p=0.009 \text { ). No differences in tumor volume were observed } \\
\text { between LFD and NCKD mice with the latter having the longest } \\
\text { survival. }\end{array}$ \\
\hline Narita [16] & 2008 & BALB/c-nu/nu & LNCap xenograft & HF (56.7\%) vs. LF $(10.2 \%)$ & Tumor volume, PSA & $\begin{array}{c}\text { Tumor volume and serum PSA levels were significantly higher in the } \\
\text { HFD group than in the LFD group. }\end{array}$ \\
\hline
\end{tabular}


Table 1. Cont

\begin{tabular}{|c|c|c|c|c|c|c|}
\hline Authors & Years & Animal Models & Tumors & Diet Summary & End Point & Summary of the Results \\
\hline $\begin{array}{l}\text { Mavropoulos } \\
\quad[21]\end{array}$ & 2009 & SCID & LNCaP xenograft & $\begin{array}{l}\text { NCKD ( } 83 \% \text { fat) vs. LFD }(12 \% \\
\text { fat) vs. WD ( } 40 \% \text { fat) }\end{array}$ & Tumor growth, survival & $\begin{array}{l}\text { Tumor volumes in the WD group remained significantly larger than } \\
\text { tumor volumes in the LFD and NCKD groups. Survival was } \\
\text { significantly prolonged for the LF (hazard ratio, } 0.49 ; 95 \% \text { confidence } \\
\text { interval, } 0.29-0.79 ; p=0.004 \text { ) and NCKD groups (hazard ratio, 0.59; } \\
\quad 95 \% \text { confidence interval, } 0.37-0.93 ; p=0.02 \text { ). }\end{array}$ \\
\hline Tamura [22] & 2009 & Nude mice & LNCaP xenograft & HFD (14\%) vs LFD (6\%) & Tumor growth & $\begin{array}{l}\text { LNCaP-Mock cells did not reveal any significantgrowth promotion by } \\
\text { breeding with HFD. HFD breeding significantly promoted the growth } \\
\text { of LNCaP-ELOVL7- } 1 \text { cells in vivo }(p=0.0081) \text {. }\end{array}$ \\
\hline Kalaany [23] & 2009 & $\begin{array}{l}\text { Prostate-specific Pten } \\
\text { deletion mouse }\end{array}$ & & Ad libitum vs. CR & $\begin{array}{l}\text { Percentage of } \\
\text { proliferation and } \\
\text { apoptosis }\end{array}$ & $\begin{array}{l}\text { CR did not affect a PTEN-null mouse model of prostate cancer but } \\
\text { significantly decreased tumor burden in a mouse model of lung cancer } \\
\text { lacking constitutive PI3K signaling. }\end{array}$ \\
\hline $\begin{array}{l}\text { Bushemeyer } \\
{[24]}\end{array}$ & 2010 & SCID & LAPC-4 xenograft & 7 types of diet & Tumor growth, survival & $\begin{array}{l}\text { No significant differences in tumor volume were observed among the } \\
\text { various groups at any time point. Overall, the treatment group was } \\
\text { not significantly related to survival. }\end{array}$ \\
\hline Llaverias [25] & 2010 & TRAMP mouse & & WD $(21.2 \%)$ vs. chow $(4.5 \%)$ & $\begin{array}{l}\text { Prostate tumor incidence } \\
\text { and progression }\end{array}$ & $\begin{array}{l}\text { TRAMP mice fed a WD were shown to develop larger tumors } \\
\text { compared to mice fed a chow diet. } 67 \% \text { ( } 6 \text { of } 9 \text { mice) of TRAMP mice } \\
\text { fed a WD exhibited at least one metastatic focus, whereas } 43 \% \text { ( } 3 \text { of } 7 \\
\text { mice) of mice fed a chow diet exhibited the same. }\end{array}$ \\
\hline Lloyd [26] & 2010 & SCID & LAPC-4 xenograft & WD $(40 \%)$ vs. chow $(12 \%)$ & Tumor growth, survival & $\begin{array}{l}\text { No difference in tumor growth or survival between chow and WD } \\
\text { was observed. }\end{array}$ \\
\hline Aronson [27] & 2010 & & $\begin{array}{l}\text { LNCaP cultured with } \\
\text { human serum }\end{array}$ & $\begin{array}{l}\text { PCa men with LF, high-fiber, } \\
\text { soy protein-supplemented diet } \\
\text { or WD for } 4 \text { weeks }\end{array}$ & Cell growth & $\begin{array}{l}\text { LF, high-fiber, soy protein-supplement diet decreased LNCaP cancer } \\
\text { cell growth. }\end{array}$ \\
\hline Masko [28] & 2010 & SCID CB17 & LAPC-4 xenograft & $\begin{array}{l}\text { NCKD ( } 84 \% \text { fat), } 10 \% \\
\text { carbohydrate diet ( } 74 \% \text { fat), or } \\
20 \% \text { carbohydrate diet } \\
\text { (64\% fat). }\end{array}$ & $\begin{array}{l}\text { Tumor volume, PSA, } \\
\text { survival }\end{array}$ & $\begin{array}{c}\text { Tumors were significantly larger in the } 10 \% \text { carbohydrate group on } \\
\text { days } 52 \text { and } 59(p<0.05) \text { and at no other point during the study. Diet } \\
\text { did not affect survival }(p=0.34) .\end{array}$ \\
\hline Akinsete [29] & 2012 & $\begin{array}{l}\text { C3 (1) Tag transgenic } \\
\text { mouse }\end{array}$ & & High $\omega-6$ vs. $\omega-3$ diet & $\begin{array}{l}\text { Tumor progression, } \\
\text { apoptosis }\end{array}$ & $\begin{array}{l}\text { Slower progression of tumorigenesis and enhanced apoptosis was } \\
\text { observed in dorsalateral prostate of high } \omega-3 \text { diet mice than in high } \\
\qquad \omega-6 \text { diet mice. }\end{array}$ \\
\hline Mao [30] & 2012 & $\begin{array}{l}\text { Homozygous } \\
\text { prostate-specific } \\
\text { RXR } \alpha \text { knockout } \\
\text { mouse }\end{array}$ & & $\begin{array}{l}\mathrm{NWD} \text { (higher fat content, } \\
\text { reduced calcium, vitamin D, } \\
\text { and fiber) or AIN-76A }\end{array}$ & & $\begin{array}{l}\text { A significant joint effect of NWD and RXR } \alpha \text { status in developing } \\
\text { mPIN, but interaction was not significant owing to the small } \\
\text { sample size. }\end{array}$ \\
\hline Bonorden [31] & 2012 & $\begin{array}{l}\text { a) TRAMP mouse, b) } \\
\text { C57/BL6 }\end{array}$ & $\begin{array}{l}\text { b) TRAMP-C2 } \\
\text { allograft }\end{array}$ & $\begin{array}{l}\text { LFD (AIN-93M) vs. } \\
\text { AIN-93M-HFD (33\%) }\end{array}$ & $\begin{array}{l}\text { a) tumor differentiation, } \\
\text { percentage of metastasis, } \\
\text { b) tumor weight and } \\
\text { volume }\end{array}$ & $\begin{array}{c}\text { No difference in the prostates of TRAMP mice. TRAMP-C2 cells grew } \\
\text { faster when the mice were fed a HFD. }\end{array}$ \\
\hline
\end{tabular}


Table 1. Cont

\begin{tabular}{|c|c|c|c|c|c|c|}
\hline Authors & Years & Animal Models & Tumors & Diet Summary & End Point & Summary of the Results \\
\hline Konijeti [32] & 2012 & SCID & $22 \mathrm{Rv} 1$ & $\begin{array}{l}\text { HFD }(43.3 \%)+\text { saline, HFD + } \\
\text { IGF-1R-Ab, LFD }(12.4 \%)+ \\
\text { saline, LFD + IGF-1R-Ab }\end{array}$ & Tumor volume & $\begin{array}{l}\text { No significant differences in final tumor volumes or final tumor } \\
\text { weights were observed between the treatment groups. At day } 14 \text { of } \\
\text { the intervention, the mean tumor volume was significantly lower in } \\
\text { the LFD + IGF-1R-Ab group than in the HF group. }\end{array}$ \\
\hline Huang [33] & 2012 & BALB/c-nu/nu & LNCaP xenograft & $\begin{array}{l}\text { HFD ( } 59.9 \%) \text { vs. } \mathrm{HCD}(9.5 \%) \\
\text { vs CD }(41.2 \%)\end{array}$ & Tumor volume & $\begin{array}{l}\text { The tumor growth of LNCaP xenograft was significantly higher in the } \\
\text { HFD group than in the HCD and CD groups. }\end{array}$ \\
\hline Wang [34] & 2012 & $\begin{array}{l}\text { a) nude mice, b) } \\
\text { Prostate-specific Pten } \\
\text { deletion mouse }\end{array}$ & a) pten-/- allograft & High $\omega-6$ vs $\omega-3$ diet & $\begin{array}{l}\text { a) tumor volume and } \\
\text { weight, b) body weight, } \\
\text { invasion rate, Ki67 }\end{array}$ & $\begin{array}{l}\omega-3 \text { PUFA resulted in slower growth of castration-resistant tumors } \\
\text { compared to } \omega-6 \text { PUFA. }\end{array}$ \\
\hline Vandelsluis [35] & 2013 & $\mathrm{Nu} / \mathrm{nu}$ athymic mice & LNCaP xenograft & $\operatorname{HFD}(23.8 \%)$ vs. SD $(6.0 \%)$ & Tumor volume & $\begin{array}{l}\text { The HF with exercise group showed significantly higher tumor } \\
\text { growth rates compared to all other groups. The SD with exercise } \\
\text { group had significantly lower tumor growth rates of compared to the } \\
\text { HFD without exercise group. }\end{array}$ \\
\hline Pommier [36] & 2013 & $\begin{array}{l}\text { C57BL/6 Lxra and } \\
\text { Lxrb double knockout } \\
\text { mice }\end{array}$ & & $\begin{array}{l}\text { Normal or } \\
\text { hypercholesterolemic diet }\end{array}$ & $\begin{array}{l}\text { Presence of PIN, number } \\
\text { of Ki- } 67 \text { positive cells }\end{array}$ & $\begin{array}{l}\text { High-cholesterol diet induced proliferation in LXR mutant mouse } \\
\text { prostate. }\end{array}$ \\
\hline Huang [37] & 2014 & BALB/c-nu/nu & LNCaP xenograft & HFD (59.9\%) vs. LFD (9.5\%) & Tumor volume & $\begin{array}{c}\text { The tumor growth of LNCaP xenograft was significantly higher in the } \\
\text { HFD group than the LFD groups. }\end{array}$ \\
\hline Moiola [38] & 2014 & Swiss nu/nu & PC-3 xenograft & HFD (homemade) vs. CD & Tumor volume & $\begin{array}{l}\text { No significant differences in tumor growth were observed in CD-fed } \\
\text { mice; however, we found that only } 60 \% \text { of HFD-fed mice inoculated } \\
\text { with CtBP1-depleted cells developed a tumor. }\end{array}$ \\
\hline Chang [39] & 2014 & TRAMP mouse & & $\operatorname{HFD}(45 \%)$ vs. $\mathrm{CD}(10 \%)$ & Histophathologica score & $\begin{array}{l}\text { Histopathological scores in the dorsal and lateral lobes were higher in } \\
\text { the 10-week HFD group than in the } 10 \text {-week CD group. }\end{array}$ \\
\hline Liu [40] & 2015 & $\begin{array}{l}\text { Pten } \\
\text { haploinsufficientmale } \\
\text { mice }\end{array}$ & & High calorie vs. regular diet & mPIN score & $\begin{array}{l}\text { High-calorie diet caused neoplastic progression, angiogenesis, } \\
\text { inflammation, and epithelial-mesenchymal transition }\end{array}$ \\
\hline Cho [41] & 2015 & $\begin{array}{l}\text { a) TRAMP, b) } \\
\text { C57BL/6J }\end{array}$ & $\begin{array}{l}\text { b) TRAMPC2 } \\
\text { allograft }\end{array}$ & $\operatorname{HFD}(60 \%)$ vs. CD $(10 \%)$ & $\begin{array}{l}\text { Rate of poorly } \\
\text { differentiated ca, tumor } \\
\text { weight }\end{array}$ & $\begin{array}{l}\text { In TRAMP mice, HFD feeding increased the incidence of poorly } \\
\text { differentiated carcinoma. In the allograft model, HFD increased solid } \\
\text { tumor growth and the expression of proteins related to } \\
\text { proliferation/angiogenesis. }\end{array}$ \\
\hline $\mathrm{Xu}[42]$ & 2015 & TRAMP & & HFD ( $40 \%)$ vs. ND (16\%) & $\begin{array}{c}\text { Tumor formation rate, } \\
\text { survival }\end{array}$ & $\begin{array}{c}\text { The mortality of TRAMP mice from HFD group was significantly } \\
\text { higher than that of normal diet group ( } 23.81 \% \text { and } 7.14 \%, p=0.035) \text {. } \\
\text { The tumor incidence of HFD TRAMP mice at 20th week was } \\
\text { significantly higher than normal diet group ( } 78.57 \% \text { and } 35.71 \%, p= \\
0.022)\end{array}$ \\
\hline $\mathrm{Xu}$ [43] & 2015 & TRAMP & & HF $(40 \%)$ vs. ND $(16 \%)$ & $\begin{array}{c}\text { Tumor incidence, } \\
\text { survival }\end{array}$ & $\begin{array}{l}\text { TRAMP mice in HFD group had significantly higher mortality rates } \\
\text { than those in the normal diet group }(p=0.032) \text {. The HFD group had a } \\
\text { significantly higher tumor formation rate at age } 20 \text { weeks than the } \\
\text { normal diet group }(p=0.045) \text {. }\end{array}$ \\
\hline
\end{tabular}


Table 1. Cont

\begin{tabular}{|c|c|c|c|c|c|c|}
\hline Authors & Years & Animal Models & Tumors & Diet Summary & End Point & Summary of the Results \\
\hline Lo [44] & 2016 & SCID & $\begin{array}{c}\text { PDX kidney capsule } \\
\text { xenograft }\end{array}$ & HF $(43 \%)$ vs LF $(6 \%)$ & $\begin{array}{l}\text { Pathology and biomarker } \\
\text { expression }\end{array}$ & $\begin{array}{l}\text { Prostate cancer tumorigenicity is not accelerated in the setting of } \\
\text { diet-induced obesity or in the presence of human PPAT. }\end{array}$ \\
\hline Liang [45] & 2016 & $\begin{array}{l}\text { Immunocompetent } \\
\text { FVB mice }\end{array}$ & MycCap alloraft & High $\omega-6$ vs. $\omega-3$ diet & Tumor volume & $\begin{array}{l}\text { Tumor volumes were significantly smaller in the } \omega-3 \text { than in the } \omega-6 \\
\text { group }(p=0.048) .\end{array}$ \\
\hline Huang [46] & 2016 & BALB/c-nu/nu & LNCap xenograft & $\operatorname{HFD}(59.9 \%)$ vs LF $(9.5 \%)$ & $\begin{array}{c}\text { Intratumoral AKT and } \\
\text { Extracellular } \\
\text { Signal-regulated Kinase } \\
\text { (ERK) activation, AMPK } \\
\text { inactivation }\end{array}$ & HFD resulted in AKT and ERK activation and AMPK inactivation. \\
\hline Labbe [47] & 2016 & $\begin{array}{l}\text { Prostate specific Pten } \\
\text { and Ptpn1 deletion } \\
\text { mouse }\end{array}$ & & HFD vs. chow & Microinvasive rate & $\begin{array}{l}\text { PCa in Pten-/-Ptpn1-/- mice was characterized by increased cell } \\
\text { proliferation and Akt activation, interpreted to reflect a heightened } \\
\text { sensitivity to IGF-1 stimulation upon HFD feeding }\end{array}$ \\
\hline Kwon [48] & 2016 & $\begin{array}{c}\text { 14K-creER PTEN } \\
\text { (K14-CreER;Pten fl/flil;mTm } \\
\text { (K14-Pten-mTmG) } \\
\text { triple transgenic mice }\end{array}$ & & HFD vs. RD & PIN $3 / 4$ rate & HFD increased the number of PIN. \\
\hline Zhang [49] & 2016 & C57BL6 & $\begin{array}{l}\text { RM1 mouse prostate } \\
\text { cancer alloglaft }\end{array}$ & HFD (58\%) vs. chow & Tumor growth & $\begin{array}{l}\text { CXCL1 chemokine gradient was required for the obesity-dependent } \\
\text { tumor ASC recruitment, vascularization and tumor growth promotion }\end{array}$ \\
\hline Chang [50] & 2017 & C57BL6 & & HFD $(45 \%)$ vs. chow & $\begin{array}{l}\text { Cav-1 secretion from } \\
\text { adipose tissue }\end{array}$ & $\begin{array}{l}\text { Cav-1 secretion was evident in adipose tissues and were substantially } \\
\text { promoted in HFD-fed mice. }\end{array}$ \\
\hline Kim [51] & 2017 & SCID & PC-3 xenograft & $10 \%, 45 \%$, or $60 \%$ fat & Tumor size, tumor weight & $\begin{array}{l}\text { The } 45 \% \text { and } 60 \% \text { fat diets significantly promoted the growth of } \\
\text { xenografts comparison to the } 10 \% \text { fat diet }\end{array}$ \\
\hline Nara [52] & 2017 & a) BALB/c-nu/nu & $\begin{array}{l}\text { a) LNCap xenograft, } \\
\text { b) PC-3 and DU145 } \\
\text { cultured with mice } \\
\text { serum }\end{array}$ & $\operatorname{HFD}(59.9 \%)$ vs. $\mathrm{CD}(9.5 \%)$ & $\begin{array}{l}\text { a) Tumor volume, b) cell } \\
\text { proliferation }\end{array}$ & $\begin{array}{l}\text { The tumor growth of prostate cancer LNCaP xenograft was } \\
\text { significantly higher in the HFD group than in the CD groups. Cells } \\
\text { cultured with HFD mouse serum had higher proliferation. }\end{array}$ \\
\hline Huang [53] & 2017 & BALB/c-nu/nu & $\begin{array}{l}\text { Intraperitoneal } \\
\text { injection } \\
\text { PC-3M-luc-C6 }\end{array}$ & HFD $(59.9 \%)$ vs. LF $(9.5 \%)$ & $\begin{array}{l}\text { Luciferase activity (IVIS), } \\
\text { number of metastasis }\end{array}$ & HFD and PrSC increased luciferase activity and number of metastasis. \\
\hline Hayashi [54] & 2018 & $\begin{array}{l}\text { Prostate-specific Pten } \\
\text { deletion mouse }\end{array}$ & & $\operatorname{HFD}(62.2 \%)$ vs. $\mathrm{CD}(12.5 \%)$ & Tumor growth & HFD accelerated tumor growth alogn with the inflammatory response. \\
\hline Massillo [55] & 2018 & C57BL/6J & TRAMP C1 allograft & $\operatorname{HFD}(37 \%)$ vs. $\mathrm{CD}(5 \%)$ & Tumor volume & $\begin{array}{l}\text { HFD significantly increased tumor growth and serum estradiol in } \\
\text { mice. }\end{array}$ \\
\hline Chen [56] & 2018 & $\begin{array}{l}\text { Prostate specific Pten } \\
\text { and Pml deletion } \\
\text { mouse }\end{array}$ & & HFD $(60 \%)$ vs. chow $(17 \%)$ & $\begin{array}{l}\text { Rate of mice having } \\
\text { metastases }\end{array}$ & $\begin{array}{l}\text { A HFD-derived metastatic progression and increases lipid abundance } \\
\text { in prostate tumors }\end{array}$ \\
\hline Hu [57] & 2018 & TRAMP & & $\operatorname{HFD}(40 \%)$ vs. CD $(16 \%)$ & $\begin{array}{l}\text { Proportion of poor tumor } \\
\text { differentiation and tumor } \\
\text { metastasis }\end{array}$ & $\begin{array}{l}\text { A trend toward poorer PCa differentiation was observed in HFD-fed } \\
\text { mice, while no statistical significance was detected. }\end{array}$ \\
\hline
\end{tabular}

Abbreviations: HFD: high-fat diet, LFD: low-fat diet, HC: high-calorie diet, LC: low-calorie diet, NKCD: high-fat/no-carbohydrate ketogenic diet, WD: Western-style diet, CR: calorie restriction, Ab: antibody, SD: standard diet, CD: control diet, PDX: patient-derived xenograft, NWD: new Western-style diet. 


\subsection{Human Cancer Cell Xenograft and Allograft Models}

The most experienced models to assess the impact of dietary fats on prostate cancer growth were subcutaneous xenograft models [11,12,15,16,35,52,58].

Nude [16] and severe combined immunodeficient (SCID) mice [15] were frequently used as host mice for human prostate cancer cell xenografts. In 1995, Wand et al. first assessed the impact of five different fat percentages on human prostatic adenocarcinoma (LNCaP) xenograft growth using athymic nude mice [11]. Accordingly, mice who continued to receive a $40.5-\mathrm{kcal} \%$ fat diet had substantially greater tumor growth rates, final tumor weights, and final tumor weight to animal weight ratios compared to those whose diets were changed to $2.3 \mathrm{kcal} \%, 11.6 \mathrm{kcal} \%$, or $21.2 \mathrm{kcal} \%$ fat, suggesting that those fed low-fat diets (LFDs) had decreased growth of established LNCaP tumors. An additional study demonstrated that an isocaloric LFD (12 kcal\% fat) resulted in significantly slower tumor growth rates and lower serum prostate-specific antigen (PSA) levels compared to a high-fat diet (HFD) using LAPC-4 xenografts on SCID mice [15]. The same group also showed that reduced dietary fat intake delayed conversion from androgen-sensitive to androgen-insensitive prostate cancer and significantly prolonged survival of SCID mice bearing LAPC-4 xenografts [58]. Moreover, we had previously found that Balb/c-nu/nu mice receiving a HFD had significantly higher LNCaP xenograft tumor volumes and serum PSA levels than those receiving an LFD [52]. The impact of a HFD on xenograft tumor growth using other human prostate cancer cell lines, such as $22 \mathrm{Rv}-1$ and PC-3, had also been investigated in previous literatures [32,51]. Although the significance of the effect varied, a number of studies proposed that a HFD accelerated tumor growth of human prostate cancer cell xenografts inoculated into immunodeficient mice. Conversely, several studies have found no relationship between a HFD and xenograft growth $[22,26]$. In a study comparing LAPC-4-xenografted SCID mice receiving an isocaloric Western diet ( $40 \%$ fat and $44 \%$ carbohydrate) and those receiving an LFD (12\% fat and 72\% carbohydrate), the authors found no difference in tumor growth or survival between both groups when saturated fat was used as the fat source [26]. Another study showed no difference in LNCaP tumor size between normal ( $6 \%$ fat) and high-fat (14\% fat) diets [22]. Taken together, a number of studies involving subcutaneous human prostate cancer cell xenografts in immunodeficient mice suggested an association between HFD and xenograft growth, whereas several other studies showed no such relationship. The lack of standardization in terms of models and duration of specific diet feeding has remained problematic.

Given the variations in the genetic background of mouse strains, it is important to consider the importance of the immune system in tumor progression [59]. Several studies have investigated the impact of dietary fat on allografts using immunocompetent mice and mouse-derived prostate cancer cells $[31,41,45,49,55]$. Several groups have shown that a HFD significantly increased allograft tumor growth of TRAMP-derived prostate cancer cells, such as TRAMP-C1 and TRAMP-C2, in C57BL6 mice $[31,41,55]$. The study involving the largest number of allografts (low-fat; $n=40$, high-fat; $n=134$ ) revealed that mice receiving AIN-93M-high-fat diet had significantly heavier and significantly larger TRAMP-C2 allografts compared to those receiving AIN-93M, whereas no differences in prostate weight were observed among the groups [31]. This result suggests that TRAMP allografts derived from C57BL6 mice can be one of the promising allograft models when studying HFD-induced prostate cancer progression.

A unique study involving a peritoneal dissemination model established through intracorporeal injection of PC-3M-luc cells detected using the Xenogen IVISTM system reported that a HFD increased tumor formation rates and total metastasis rates in the peritoneal organs [53].

In summary, given that most of the xenograft and allograft studies were performed using subcutaneous xenograft models, studies involving metastatic models and human patient-derived xenografts (PDXs) have been lacking. Although several studies using xenografts and allografts have shown that a HFD accelerated tumor growth, further validation is warranted. 


\subsection{TRAMP Mouse Models}

Since its generation in 1996, the TRAMP mouse model has been one of the most widely used models in prostate cancer research [60]. This model represents a transgene comprising the minimal probasin promoter driving viral SV40 large-T and small-t antigens, which lead to prostate-specific inactivation of $\mathrm{pRb}$ and $\mathrm{p53}$, specifically in the prostatic epithelium [61]. TRAMP mice develop prostatic intraepithelial neoplasia (PIN) by the time they are 6 weeks old; this progresses to high-grade PIN by the age of 12 weeks and poorly differentiated and invasive adenocarcinoma by the age of 24 weeks, with nearly $100 \%$ penetrance [61]. The impact of a HFD on the growth of TRAMP mouse tumors had been frequently evaluated [25,31,39,41-43,57,62]. Accordingly, Llaverias et al. showed that mice consuming a Western-type diet enriched in both fat and cholesterol had higher prostate tumor incidence and greater tumor burden compared to those fed a control chow diet [25]. After necropsy at 28 weeks, $33 \%$ of TRAMP mice fed a Western diet showed grossly evident spherical prostate tumors, whereas only $17 \%$ of TRAMP mice fed a chow diet exhibited the same [25]. In another study on TRAMP mice, $\mathrm{Xu}$ et al. revealed that the HFD group had significantly higher mortality than the normal diet group ( $23.81 \%$ and $7.14 \%$, respectively, $p=0.035)$. Moreover, HFD-fed TRAMP mice had significantly higher tumor incidence at 20 weeks, as compared to the normal diet group (78.57\% and $35.71 \%, p=0.022$, respectively) [43]. The same group also showed that HFD-fed mice suffered higher rates of extracapsular extension ( 20 weeks, $16.7 \%$ vs. $8.3 \%$; 28 weeks, $66.7 \%$ vs. $50.0 \%$, respectively) and distant metastasis (e.g., retroperitoneal lymph nodes or lung metastasis) (28 weeks, $41.7 \%$ vs. $25.0 \%$, respectively) [62]. Bonorden et al. conducted a unique study involving the largest number of mice ( $n=25$ each) to assess the direct effect of diet and body weight on prostate tumors. TRAMP mice received low- and high-fat diets with the latter being divided into three groups: obesity-prone (the heaviest third), overweight (the middle third), and obesity-resistant (the lightest third). Accordingly, their results showed that body weight or diet had no effect of on either age at tumor detection, neuroendocrine status, or age at death [31]. Taken together, the impact of a HFD on tumor incidence and survival of TRAMP mice still remains controversial. The timing of diet change, selection of control diet, and diet ingredients may be important in establishing HFD-accelerated orthotopic prostate tumor models in TRAMP mice.

\subsection{Other Genetically Engineered/Transgenic Mouse Models Targeting Oncogenes and Tumor Suppressor Genes}

Several studies have investigated the effect of dietary fat on prostate cancer development and progression using genetically engineered mouse models (GEMMs) targeting oncogenes and tumor suppressor genes $[19,29,30,36,40,47,48,54,56]$. Designated Hi-myc uses a PB promoter coupled with a sequence of the ARR2 promoter, both of which lie upstream to the human c-Myc gene, in order to drive progression from mouse prostatic intraepithelial neoplasia (mPIN) to invasive adenocarcinoma [63]. Using this animal model, Kobayashi et al. showed that the HFD group ( $42 \mathrm{kcal} \%$ fat) had a greater number of invasive adenocarcinoma and a higher proliferative index in the PIN region compared to the LFD group (12 kcal\% fat) [19]. Phosphatase And Tensin Homolog (Pten) alteration has been shown to be an early event in prostate cancer initiation and progression. Moreover, Pten-null mice that develop PIN have among the valuable animal models in prostate cancer research [64]. Kalaany et al. showed that $40 \%$ dietary restriction did not have any detectable effect on the extent or histological appearance of the PIN in Probasin-Cre; PTEN L/L prostate cancer models but significantly reduced tumor nodules in the lungs of K-RAS ${ }^{\mathrm{LA} 2}$; P53 LSL/WT lung adenocarcinoma models [23], suggesting that the Phosphoinositide 3-kinase (PI3K)/ protein kinase B (AKT) pathway is critical for diet-induced cancer progression. Conversely, a high-calorie diet ( $45 \mathrm{kcal} \%$ fat) promoted prostate cancer progression in genetically susceptible Pten haploinsufficient mice with increasing inflammatory response in the presence of enhanced insulin response to chronically elevated insulin levels [40]. Hayashi et al. demonstrated that mice receiving a HFD for 17 weeks starting from an age of 5 weeks had significantly higher prostate weights of than those receiving control [54]. Moreover, HFD-fed model mice had a significantly higher Ki67-positive cell to tumor cell ratio than control mice, while no marked difference 
in glandular structures was observed between the control diet (CD)-fed and HFD-fed model mice [54]. An interesting study involving the basal cell-specific Pten-null model using K14-Pten-mTmG mice showed that HFD intake promoted the initiation and progression of PIN lesions [48]. Although dietary fat could potentially be associated with prostate cancer development of Pten-null mice, the impact may not be extensive. Additionally, the evaluation of prostate pathology in GEMMs needs to be standardized according to the Consensus Report from the Bar Harbor Meeting of the Mouse Models of Human Cancer Consortium Prostate Pathology Committee for accurate comparison among different studies [65].

With regard to other GEMMs, PTP1B (PTPN1), an androgen-regulated phosphatase, acts as a HFD-dependent tumor suppressor in prostate cancer driven by the absence of Pten, such as in the Pten-/-Ptpn1-/- mice model [47]. Deficiency in RXR $\alpha$ (a unique and important member of the nuclear receptor superfamily) in the prostates of mice receiving a new Western-style diet resulted in higher rates of mPIN and prostate cancer [30]. Pommier et al. showed that mice with double knockout of Liver $X$ receptors (LXRa and LXRb), which belong to the nuclear receptor superfamily and are central mediators of cholesterol homeostasis, developed PIN under a diet high in cholesterol [36].

Reports regarding HFD-induced metastatic models using GEMMs have been rare. Chen et al. showed that among mice with Pten deletion and a double deletion of Pten and Promyelocytic Leukemia (PML), a suppressor of pp1 $\alpha$-dependent activation of MAPK signaling, those receiving a lard-based HFD displayed lymph node metastasis and lung metastasis, whereas those receiving a chow diet exhibited limited metastases [56].

Taken together, GEMM studies showed that a HFD enhanced tumor growth through the modulation of several genes, including those related to PTEN. Studies that assess the impact of a HFD using more aggressive, metastatic GEMMs while considering the effect of dual and/or multiple genes may be intriguing.

\subsection{Others}

Several studies have evaluated the proliferation of prostate cancer cell lines cultured with serum from mice and humans under different diet conditions [13,27]. Two mice studies proposed that a HFD serum enhanced cell proliferation of LAPC-4 and PC-3/DU145 cells in CB17 SCID and Balb-c/nu/nu mice, respectively $[15,52]$. With regard to in vitro studies using human sera, Barnard et al. assessed the growth of LNCaP cells cultured with healthy volunteer serum according to dietary fat and exercise condition [14]. Accordingly, they found that an LFD with exercise inhibited cell growth. Subsequently, after evaluating the growth of LNCaP cells cultured with sera from patients with prostate cancer receiving a low-fat, high-fiber, soy-protein supplement diet or Western diet for 4 weeks, Aronson et al. showed that the LFD induced changes in serum fatty acid levels with decreased LNCaP cancer cell growth [27]. In an interesting study by Lo et al., PDX models of prostate cancer cells implanted into the renal capsule of SCID mice were developed [44]. Histological analysis of the PDXs showed no differences in tumor pathology; PSA, androgen receptor, and homeobox protein Nkx-3.1 expression; or proliferation index between HFD- and LFD-fed mice. Furthermore, they also evaluated the impact of co-grafting human periprostatic adipose tissue (PPAT) with prostate cancer in PDX grafts. After harvesting the PDX tissues 10 weeks after grafting, histological analysis revealed no evidence of enhanced tumorigenesis with PPAT compared to prostate cancer grafts alone. It would be intriguing to assess the effects of a HFD on PDXs with a more aggressive prostate cancer phenotype obtained from metastatic disease and co-grafting this with PPAT from patients with severe obesity considering that the aforementioned model was established using tissues from patients with localized prostate cancer treated with surgery.

\section{Differences in Diets}

A number of studies have tried to assess the impact of a fat-enriched diet on prostate cancer development and progression. However, the dietary interventions had not been standardized, while distinct variations in phenotype had been observed among different studies using distinct HFD 
components. Differences in dietary components among research models had also been reported to affect the distinct effect of diet-induced metabolic disorders [66]. Therefore, in addition to the models used, the type of diet remains essential for studies to delineate diet-induced carcinogenesis.

\subsection{Direct Comparison between Two Different Diets Including the High-Fat Diet and Another Diet}

While conclusions have been frequently drawn from comparisons between a defined HFD and chow, specific details regarding the control diet are often lacking. Many studies have utilized a chow diet as the control treatment $[25,26,49,50,56]$. Regular chow is composed of agricultural byproducts, such as ground wheat, corn or oats, alfalfa, and soybean meals; a protein source, such as fish; and vegetable oil; it is supplemented with minerals and vitamins. Thus, chow can be considered a high-fiber diet containing complex carbohydrates with fats from various vegetable sources. Chow is inexpensive to manufacture and palatable for rodents. In contrast, defined HFDs consist of amino acid-supplemented casein, cornstarch, maltodextrin or sucrose, and soybean oil or lard and are supplemented with minerals and vitamins. Fiber is often provided by cellulose. Chow and defined diets may exert significant separate and independent unintended effects on the measured phenotypes in any research protocol [66]. In sum, multiple limitations may affect the results of the target groups.

A direct comparison between two different diets including the HFD, has been used extensively to understand the role of diet on prostate cancer development and progression $[12,15,27,30,43,47,51,58]$. Most of the studies showed that HFD-fed mice had greater body weight compared to controls, which leads one to consider whether diet has a direct or indirect (obesity-induced) effect on cancer development and progression. Although majority of the previous studies proposed an association between dietary fat and prostate cancer development/progression, several limitations need to be considered. First, a multitude of proportions per calories of fat have been observed with relative fat fractions ranging between $14 \%$ and $84 \%$ energy as fat. We need to consider the fact that the higher proportions of fat used in animal studies cannot be used in human diets. Second, we need to be careful about being misled by ignoring the impact of fat components, the control diet, and other elements in each diet. For instance, Lloyd et al. showed no difference in the growth and survival of LAPC-4 xenografts between SCID mice receiving a Western-style diet, including $40 \% \mathrm{kcal}$ fat, and those fed an LFD (12\% kcal) [26]. In this study, the fat consisted of 19\% lard, 19\% milk fat, and 1.9\% corn oil. Conversely, another study demonstrated that HFD-fed SCID mice ( $42 \% \mathrm{kcal}$ ) had significantly faster LAPC-4 tumor xenograft growth and higher PSA levels compared to LFD-fed mice (12\% kcal) [15]. In this study, the HFD was composed of corn oil. These lines of evidence suggest that different effects have been observed despite having similar percentages of fat components. Finally, publication bias should be taken into account for a comprehensive understanding, because negative data tend to remain unpublished.

\subsection{Comparison of the Impact of a High-Fat Diet using Multiple Diets}

A direct comparison between multiple diets using animal models is one method of identifying the diet having the most effect on tumor growth. In our previous study, LNCaP xenograft tumor growth in Balb/c-nu/nu mice were evaluated among three groups receiving a HFD (59.9 kcal\% fat), Western-style diet (WD: $41.2 \mathrm{kcal} \% \mathrm{fat}$ ), and high carbohydrate diet (HCD: $9.5 \mathrm{kcal} \%$ fat) [33]. Accordingly, our results showed that the HFD group had significantly higher LNCaP xenograft tumor growth than the HCD and WD groups. In general, a ketogenic diet, which contains extremely high fat, is toxic to cancer [28]. Accordingly, the systematic review by Khodadadi et al. demonstrated that a ketogenic diet can potentially inhibit malignant cell growth and increase survival time [67]. Moreover, studies comparing the tumor growth and survival of LAPC-4 xenografts in SCID mice demonstrated that mice receiving a no-carbohydrate ketogenic diet (NCKD: $83 \%$ fat, $0 \%$ carbohydrate, $17 \%$ protein) had smaller tumors and higher survival than those receiving a low-fat/high-carbohydrate diet (LFD: $12 \%$ fat, $71 \%$ carbohydrate, $17 \%$ protein) or a high-fat/moderate carbohydrate diet (MCD: $40 \%$ fat, $43 \%$ carbohydrate, $17 \%$ protein) [20]. Another study also investigated the differences between three diets, namely a NCKD ( $84 \%$ fat- $0 \%$ carbohydrate- $16 \%$ protein kcal), $10 \%$ carbohydrate diet $(74 \%$ 
fat $-10 \%$ carbohydrate $-16 \%$ protein $\mathrm{kcal}$ ), and $20 \%$ carbohydrate diet $(64 \%$ fat $-20 \%$ carbohydrate $-16 \%$ protein kcal), with results showing significantly larger tumors in the $10 \%$ carbohydrate group but no difference in survival [28]. These lines of evidence suggested that extremely high fat percentages have a potential to exert an opposite effect on prostate cancer development and progression. Therefore, the proportion of total fat intake remains important.

One study using a Western-type diet (16\% protein, $40 \%$ fat, $44 \%$ carbohydrate) evaluated the impact of seven diets: Group 1, ad libitum 7 days/week; Group 2, fasted 1 day/week and ad libitum 6 days/week; Group 3, fasted 1 day/week and fed 6 days/week via paired feeding to maintain isocaloric conditions similar to that in Group 1; Group 4,14\% calorie restriction (CR) 7 days/week; Group 5, fasted 2 days/week and ad libitum 5 days/week; Group 6, fasted 2 day/ week and fed 5 days/week via paired feeding to maintain isocaloric conditions similar to that in Group 1; and Group 7, 28\% CR 7 days/week [24]. Accordingly, some of the groups did not exhibit trends toward tumor shrinkage and improved survival, although Groups 6 and 7 had lower lean body mass than Group 1 in a two-way comparison. The study implicated that intermittent calorie restriction via fasting with a Western-style diet had no impact on prostate cancer progression, despite the effect on body weight.

\subsection{Specific Components of Fat}

Each dietary fat has diverse physiological effects according to the different types and distributions of dietary fat components. Therefore, important relationships between specific types of dietary fat intake and prostate cancer development may be missed by merely evaluating the effect of total fat intake [68]. Fatty acids are classified based on whether or not the fatty acid carbon chain contains no double bond (saturated fatty acids (SFA)), one double bond (monounsaturated fatty acids (MUFA)), and more than one double bond (polyunsaturated fatty acids (PUFA)), as well as the configuration of the double bonds (cis or trans). In addition, PUFA are often classified based on the position of the first double bond from the fatty acid methyl terminus, creating omega- 3 and -6 fatty acids. The primary sources for SFA, MUFA, and PUFA include animal fats such as lard and beef tallow, animal and certain vegetable fats such as olive oil, and vegetable oil such as corn and fish oils, respectively [66]. Corn oil and most vegetable oils contain omega-6 PUFA, whereas fish oils are high in omega-3 PUFA [69].

In general, a number of previous studies made use of a lard-based HFD, which is rich in SFA. Studies in human subjects have shown that SFA are more oncogenic than PUFA [70]. Moreover, several studies have shown that cancerous tissues exhibited elevated SFA and MUFA compared to adjacent normal tissues [71,72]. Mice receiving lard oil had been reported to have enhanced Toll-like receptor (TLR) activation and white adipose tissue inflammation, as well as reduced insulin sensitivity, compared to those receiving fish oil [69], suggesting that a diet rich in SFA accelerated metabolic inflammation. In general, MUFA, such as oleic acid and olive oil, are more likely to prevent or decrease the risk of carcinogenesis in other solid cancers, including breast and colon cancers [73]. Phenolic compounds, which prevent free radical-initiated peroxidation and regulate cancer-related oncogenes, have been considered to be associated with MUFA-induced chemoprevention [73]. Omega-3 and -6 PUFA are essential fatty acids that mammals can neither synthesize nor de novo interconvert, suggesting that they have to be obtained from the diet [18]. From an evolutionary standpoint, the human diet has had a 1:1 ratio of omega-6-to-omega-3 PUFA [74]. Over the past two centuries, however, this ratio has increased to nearly 10:1 due primarily to the increased use of vegetable oils in Western diets [8,45]. In general, the high consumption of omega- 6 fatty acids leads to inflammation and cellular growth through the conversion of arachidonic acid (an omega- 6 fatty acid) to hydroxyeicosatetraenoic and epoxyeicosatrienoic acids by cytochrome P450 oxygenases [75]. In contrast, omega-3 induces anti-inflammatory, pro-apoptotic, anti-proliferative, and anti-angiogenic pathways, providing antitumor effects against prostate cancer [76]. Fish oil, which contains omega-3 fatty acids, does not cause obesity because of peroxidization [77] and induces the activation of peroxisome proliferator-activated receptor alpha. These lines of evidence suggest that omega- 3 and -6 PUFA have different effects on diet- and obesity-induced prostate cancer development and progression. 
Three studies had reported on the difference in tumor growth between diets rich in omega- 3 and $-6[18,29,45]$. Accordingly, mice fed a high omega-3 diet had significantly lesser prostate weight gain than those fed a high omega- 6 diet. Moreover, half of the mice fed a high omega-3 diet developed invasive carcinoma, whereas $80 \%$ of mice fed a high omega- 6 diet had invasive carcinoma [18]. The second study revealed that fish oil slowed the progression of tumorigenesis in dorsolateral prostate C3 (1) tag transgenic mice [29]. The last study, which established MycCaP allografts in immunocompetent FVB mice, found that the $\omega-3$ group had significantly smaller tumor volumes than the $\omega-6$ group [45]. All three different models successfully confirmed that omega- 3 inhibited tumor growth, which suggests the promising inhibitory effects of omega- 3 fatty acid against prostate tumors.

Cholesterol, an organic compound, is a key component of membrane signaling microdomains. In humans, cholesterol can be either obtained from diet or synthesized de novo in the liver. Animal studies using the cholesterol uptake inhibitor ezetimibe for prostate cancer chemoprevention showed that lowering serum cholesterol level slows tumor growth and decreases angiogenesis and intratumoral androgens [78]. Pommier et al. demonstrated that a high-cholesterol diet induced proliferation in LXR mutant mouse prostate [36]. In a clinical setting, the meta-analysis performed by Bonovas et al. was the only study to find a significantly reduced incidence of advanced prostate cancer in subjects who were prescribed statins; however, no relationship between statin use and overall prostate cancer risk was demonstrated in other studies [79]. The observational study by Murtola et al. reported a dose-dependent, significant inverse association between overall prostate cancer incidence and statin use, with the strongest inverse association for early-stage prostate cancer [80]. However, clinical evidence on the protective effect of cholesterol-lowering drugs for prostate cancer chemoprevention is still weak and inconsistent; therefore, we are unable to draw a firm conclusion based on these results.

Finally, care should be taken when establishing how much of a role other nutrients contained in experimental diets have and the actual consumption of diets in each mouse given that the proportion of other ingredients changes when the percentage of fat components is modulated.

\section{Potential Mechanisms}

Previous studies have proposed several mechanisms in order to explain the possible association between dietary fat and prostate cancer development/progression. Accordingly, growth factor signaling, lipid accumulation, inflammation, and endocrine modulation had been hypothesized to be associated with HFD-induced prostate cancer development and/or progression (Figure 1). Certainly, a more thorough understanding of the possible association between dietary fat and prostate cancer risk requires further inquiry.

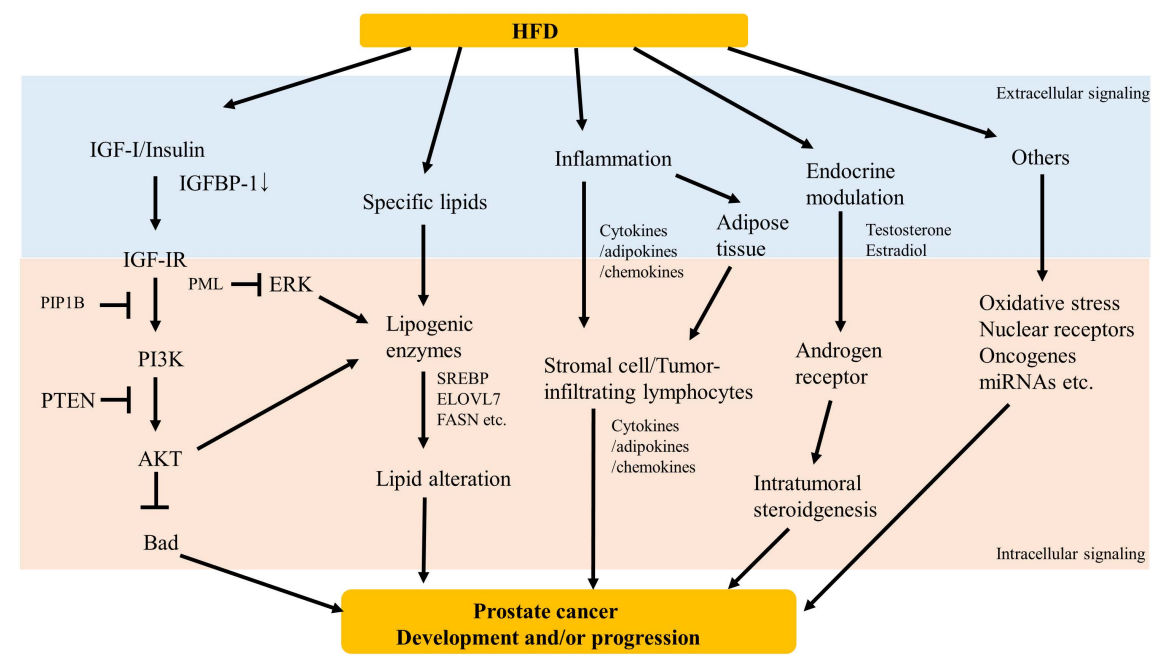

Figure 1. Scheme of potential mechanisms underlying high-fat diet induced prostate cancer development and/or progression. 


\subsection{Growth Factor Signaling}

Obesity and hyperinsulinemia have been associated with increased amounts of circulating bioactive insulin-like growth factor-I (IGF-I), a growth factor determined to play a pathogenic role in many cancers [81]. Barnard et al. demonstrated that dietary fat reduction combined with a regular exercise intervention in men decreased serum IGF-I and increased serum IGFBP-1 levels, resulting in decreased growth of LNCaP human prostate cancer cells cultured in media containing volunteer serum [14]. The same group showed that LFD-fed mice had significantly slower tumor growth rates, lower levels of serum insulin, tumor IGF-I mRNA expression, and tumor IGFBP-2 immunostaining, and higher levels of serum IGFBP-1, which indicated that IGF-I signaling modulated fat-induced tumor growth in LAPC-4 xenografts [15]. We had previously demonstrated that IGF-I receptor (IGF-IR) mRNA levels were strikingly elevated in HFD-accelerated LNCaP xenografts and that the group having the lowest IGF-IR immunoreactivity tended to have the lowest body mass index in both human normal and prostate cancer epithelia [16]. Kobayashi et al. showed that an LFD reduced the development of prostate cancer in Hi-Myc mouse transgenic model with the suppression of the IGF-AKT pathway, which leads to higher serum IGFBP-1 levels, reduced serum mitogenicity, and lower AKT, GSK3beta, and S6K activities [19].

Several studies have demonstrated that hyperactivation of PI3K-AKT, which is one of the downstream targets for IGF-I signaling, desensitizes tumors to dietary modulations, including calorie restriction and a HFD $[23,47]$. The PI3K/AKT pathway is naturally inhibited by Pten, which is one of the most frequently lost or mutated tumor suppressor genes in prostate cancer [56]. Partial loss of PTEN is observed in 70\% of localized prostate cancer, while complete loss thereof is associated with metastatic castration-resistant prostate cancer [56]. PTEN inactivation also induces aberrant activation of the PI3K/AKT pathway. As previously mentioned, conditional PTEN knockout produces indolent tumors in mouse prostates. One study that assessed the impact of diet restriction revealed that it does not affect a PTEN-null mouse model of prostate cancer but significantly decreases tumor burden in a mouse model of lung cancer lacking constitutive PI3K signaling, which suggests that PI3K signaling is strongly associated with diet-induced cancer progression [23]. Another study involving a GEMM mouse model showed that the loss of both PTEN and the protein tyrosine phosphatase Pypn1, a negative regulator of IGF-IR, enabled the development of a highly invasive prostate tumor, whereas PTEN deficiency alone resulted in tumors that were unresponsive to HFD [47]. Collectively, mechanisms involving PTEN and other related genes may have a higher impact on diet-induced prostate cancer development and progression.

Many other studies have proposed that IGF-I/PI3K/AKT signaling has an impact on diet-induced prostate cancer development and progression $[21,28,43]$. Therefore, IGF-I/PI3K/AKT signaling has been one of the promising pathways related to HFD-induced prostate cancer development and progression. To determine the impact of treatment, the additive effect of IGF-1R inhibition using IGF-IR blockade antibody on 22Rv1 subcutaneous xenografts in SCID mice receiving a HFD (43.3\%) or LFD (12.4\%) had been investigated [32]. Accordingly, the results showed that the LFD + IGF-1R-Ab group had a significantly smaller mean tumor volume compared to the HF group at day 14 of the intervention. However, no significant difference in final tumor volumes or final tumor weights had bene observed between the four treatment groups. Therefore, the therapeutic effect of IGF-I pathway inhibition remains unknown.

Diet-induced hyperinsulinemia has been shown to accelerate tumor growth in different prostate cancer xenograft models $[17,20]$. A large prospective survival analysis reported that higher serum C-peptide concentrations, a surrogate of insulin levels, were associated with increased prostate cancer-specific mortality [82]. Insulin and IGF-I are closely related hormones that act on specific tyrosine kinase receptors and elicit the activation of a cascade of intracellular proteins leading to the regulation of gene expression, protein synthesis, cell proliferation or death, and glucose and lipid metabolism. High insulin levels, as well as insulin receptor and IGF-I/IGF-IR axis activation, have been known to be associated with obesity induced cancer progression [83]. Regarding the impact of insulin 
levels on diet-induced prostate cancer growth, one study involving LAPC-4 xenografts in SCID mice receiving three different diets, NCKD ( $84 \%$ fat), $10 \%$ carbohydrate diet ( $74 \%$ fat), or $20 \%$ carbohydrate diet (64\% fat), proposed that mice receiving a $10 \%$ carbohydrate diet had larger tumors than the other groups despite mice receiving a $20 \%$ carbohydrate diet having the lowest insulin levels [28]. As such, future studies need to elucidate the relationship between insulin levels and diet-induced prostate cancer carcinogenesis.

In addition, effects of different fat sources on the IGF/insulin axis have rarely been discussed and studied. It would be intriguing to know the varying impacts specific fats have on HFD-induced prostate cancer development and progression through growth factor signaling.

\subsection{Lipid Accumulation}

The changes in endogenously synthesized/exogenous lipid profiles and related enzymes have been linked to prostate cancer development and progression. Accordingly, Freedland et al. showed that mice with LAPC-4 xenografts receiving a NCKD diet had low hepatic fatty infiltration, which resulted in reduced tumor growth and longer survival [20]. Genome-wide gene expression analysis showed that the lipogenic gene ELOVL7, which possibly codes a long-chain fatty acid elongase, was overexpressed in clinical prostate cancer and regulated by SREBP1. Moreover, a HFD had been found to promote the growth of in vivo tumors of ELOLV7-expresssed prostate cancer [22]. In the aggressive and metastatic tumor progression observed in TRAMP mice receiving a Western-style diet, Llaveries et al. showed that the Western-style diet increased both the expression of the high density lipoprotein receptor SR-BI and angiogenesis [25]. Fatty acid synthase (FASN) is a cytosolic metabolic enzyme that catalyzes de novo fatty acid synthesis. Our previous study found that serum FASN levels were significantly lower and were inversely correlated with tumor volume in LNCaP xenograft mice receiving HFD [46].

A recent study has suggested that a Western-style HFD promotes metastatic prostate cancer through a prometastatic lipogenic program alteration [56]. In this study, the conditional inactivation of Pml (a suppressor of pp1 $\alpha$-dependent activation of MAPK signaling) in mouse prostates changed indolent PTEN-null prostate tumors into lethal metastatic tumors with MAPK reactivation, subsequent hyperactivation of an aberrant SREBP, and a lipidomic profile alteration. Pten-/-, Pml-/- mice receiving a chow diet displayed limited lymph node metastasis. However, most mice receiving a HFD developed lymph node metastasis, while half of them had lung metastasis. Moreover, Oil Red O staining showed that the tumors in mice receiving a HFD had higher lipid accumulation compared to those in mice receiving a chow diet. Sterol responsive element binding proteins (SREBPs) have been found to be a key regulator of lipogenic genes [56]. Studies have shown that HFD feeding stimulates SREBP expression, subsequent expression of genes encoding lipogenic enzymes, and lipid accumulation in nonadipose tissues $[56,84]$. Therefore, Pml and SREBP-dependent lipogenic alterations may be associated with HFD-enhanced prostate cancer progression.

Although de novo lipogenesis has emerged as an important player in prostate cancer, the impact of exogenous dietary fat on intraprostatic lipid profiles and activity of lipogenic enzymes remains largely unknown. Future studies are required to elucidate the mechanisms for endogenous lipid alterations and exogenous fat accumulation on dietary fat-induced prostate cancer development and progression.

\subsection{Inflammation}

Inflammations have been shown to promote the development and progression of prostate cancer [85]. A HFD with consequent obesity causes adipose tissue inflammation and cytokine secretion [86]. Accordingly, Liu et al. demonstrated that Pten $+/$ - mice receiving a high-calorie diet exhibited neoplastic progression with stromal infiltration of inflammatory cells, such as macrophages, $\mathrm{T}$ cells, and inflammatory monocytes, into the prostates [40]. Additionally, the increased inflammatory response to a high-calorie diet was supported by the elevation in the expression of CD3, CD45, FoxP3, MCP-1, IL-6, and TNF alpha. Microarray analysis using TRAMP mice models showed that HFD feeding increased serum levels of MCP-1, MCP-5, TIMP-1, IL-16, CCL12, CXCL1, CXCL10, and CXCL13 [41]. 
Similar results were observed in the sera of TRAMP-C2 allograft models. Zhang et al. demonstrated that adipose stromal cell recruitment to tumors of RM1 mouse prostate cancer xenografts via CXCL1 and CXCL8 chemokines promoted prostate cancer progression [49]. Another study showed that MycCaP xenografted immunocompetent FVB mice receiving a diet rich in omega-3 exhibited tumor suppression, as well as lower gene expression of markers for M1 and M2 macrophages, associated cytokines (IL-6, TNF alpha, and IL-10), and the chemokine CCL-2. Hayashi et al. showed that a HFD increased the prostate weight and percentage of Ki67-positive MDSCs, as well as the M2/M1 macrophage ratio, in HFD-fed model mice with a higher serum IL-6 levels [54]. Furthermore, celecoxib suppressed tumor growth in HFD-fed but not CD-fed model mice, which suggested that HFD-induced tumor growth was associated with local inflammation. Taken together, tumor-infiltrating macrophages may perhaps be a key factor in HFD-induced prostate cancer progression [54]. One of our previous studies had demonstrated that the MCP-1/CCR2 pathway, a key regulator of macrophage infiltration, was highly associated with HFD-induced LNCaP xenograft tumor growth, supporting the results presented herein [33]. We also found that the expression of macrophage inhibitory cytokine 1 (MIC-1), a divergent member of the transforming growth factor beta, was stimulated by palmitic acid in vitro, while mice receiving a HFD containing high amounts of palmitic acid had LNCaP had significantly greater xenograft tumor growth, serum MIC1 levels, and fatty acid levels in xenograft tumors than those receiving an LFD in vivo [37]. Such lines of evidence suggesting the association between cytokines and tumor-macrophage interaction support the notion that tumor-associated macrophages play a role in HFD-induced prostate cancer development and progression. Another mouse xenograft experiment concluded that HFD enhanced prostate cancer metastasis and invasiveness through FABP4 and interleukin-8 upregulation [53]. FABP4, an abundant protein in adipocytes that is influenced by a HFD or obesity, may enhance prostate cancer progression and invasiveness by upregulating matrix metalloproteinases and cytokine production in the prostate cancer stromal microenvironment [53]. In one study demonstrating tumor growth decline among Pten $\mathrm{KO}$ mice receiving omega- 3 fatty acid, the group with an omega-3-enriched diet exhibited a reduction in CD3+ lymphocyte levels and tumor microvessel density [18]. These lines of evidence suggest that a stromal microenvironment, including infiltration of immune cells, is associated with dietary-fat induced prostate cancer carcinogenesis. Moreover, other cytokines and chemokines, including TWEAK, (CCL)3, CCL4, and CCL5, had been found to be potentially associated with HFD-induced prostate cancer progression according to previous literatures $[41,57,87]$.

The role of adipocyte function on HFD feeding was evaluated in a recent study [50]. Accordingly, Cav-1 secretion from fat tissue of HFD-fed mice was increased, while hypertrophied adipocytes were responsible for enhanced Cav-1 secretion in obese mice. Furthermore, secreted Cav-1 was taken up by the preadipocytes and LNCaP cells. The impact of hypertrophied adipocyte-induced Cav-1 secretion on prostate cancer progression and diet- and/or obesity-modulated adipose function could be associated with prostate inflammation and prostate carcinogenesis. Moreover, adipose tissues are known to enhance cancer progression via several underlying mechanisms, such as aromatization of adrenal androgens to estrogens in the adipocyte and deregulation of the expression and secretion of the adipokines [88,89]. Therefore, it is worthwhile to assess the role of quantitative and qualitative modulation of adipose tissues on prostate cancer progression using preclinical models.

In summary, the interaction among systematic and/or adipose secreted cytokines, inflammation, and immune cell infiltration into tumors may have a promising mechanistic role in HFD-induced prostate cancer development and progression.

\subsection{Endocrine Modulation}

Considerable epidemiological evidence has shown that fat-containing diets may increase the risk of certain hormone-dependent conditions in men via its effects on hormone metabolism [90]. Hormonal modulation has been one of the proposed mechanisms associated with diet- and/or obesity-induced prostate cancer carcinogenesis $[8,9]$ given that sex hormones play a key role during normal and 
cancerous prostate growth and development. Two transgenic mouse studies showed that omega-3 fatty acids slowed prostate tumor growth through the modulation of sex steroid pathways. In the C3 (1) Tag transgenic mice study, the lowering testosterone, estradiol, and androgen receptor levels by the action of omega-3 fatty acids promoted apoptosis and suppressed prostate epithelial cell proliferation [29]. Another study demonstrated that omega-3 PUFA treatment slowed castration-resistant tumor growth and accelerated androgen receptor protein degradation [34]. A recent study showed that although serum cholesterol reduction did not significantly affect the rate of adenocarcinoma development in the PTEN-null transgenic mouse model of prostate cancer [78], it lowered intraprostatic androgens and slowed tumor growth. These results suggest that fat-containing diets, especially those that modulate of omega-3 fatty acid content, may potentially modulate intraprostatic hormonal status associated with cancerous tumor growth and progression. In the TRAMP-C1 allograft study, HFD increased tumor growth and serum estradiol levels [55]. The study also showed that intratumoral C-terminal-binding protein 1 (CtBP1) controls the transcription of aromatase (CYP19A), a key enzyme that converts androgens to estrogens, and was overexpressed with increased TRAMP-C1 allograft tumor growth in mice receiving a HFD. In another study, Moiola et al. found that mice with CtBP1-depleted PC-3 xenografts developed significantly smaller tumors than those inoculated with PC-3 control cells [38]. These results suggest that $\mathrm{CtBP} 1$ have the potential to be a key transcriptional factor associated with intratumoral hormonal modulation and HFD-induced prostate cancer growth.

\subsection{Others}

Using microarray analysis, our group had previously showed that several mRNAs and miRNAs become altered in HFD-induced LNCaP xenografts [16,52]. Therefore, complex mechanisms, including candidate pathways mentioned previously, may be considered to contribute to fat-diet induced prostate cancer development and progression. Nara et al. demonstrated that miR-130a was attenuated in HFD-induced prostate cancer progression with MET overexpression in vitro and in vivo and that cytoplasmic MET in prostate cancer tissues was overexpressed in patients with higher body mass index [52]. Kim et al. found that a HFD not only accelerated Src-induced prostate tumorigenesis, but also compromised the inhibitory effect of the anticancer drug dasatinib on Src kinase oncogenic potential in vivo [51]. Finally, the association between diet-induced prostate cancer progression and several pathways, including oxidative stress [39], epithelial-mesenchymal transition [40], and basal/luminal differentiation [48], have been proposed in previous studies.

\section{Concluding Remarks}

Over recent years, the molecular mechanisms behind HFD-induced prostate cancer development and progression have been studied using pre-clinical models. Although several lines of evidence have proposed its relationship with potential mechanisms, such as growth factor signaling, lipid accumulation, inflammation, and endocrine modulation, the current data still remains inconclusive. In addition, the studies presented herein have used various types of models and diet sources, suggesting the need for increases vigilance when communicating and interpreting information. Therefore, it is important to consider the predictability and limitation of each preclinical model when translating experimental results into clinical practice. Although information from pre-clinical models remain important for deeper understanding and exploration of novel treatment targets, further studies are needed to validate the impact of dietary fat and obesity on prostate cancer development and progression.

Author Contributions: Conceptualization, Data collection and Writing-Original Draft Preparation, S.N.; Reviewing: T.N., H.S., M.H. and A.K. Writing-Review and Editing, T.H.; Supervision, T.I. and T.H.

Acknowledgments: This study was supported in part by research grants from the MEXT/JSPS (Kakenhi, 16H02679, 16K10992, 19K09663) and the Japan Agency for Medical Research and Development (AMED) (grant 18gm0710002h0706).

Conflicts of Interest: The authors declare no conflict of interest. 


\section{References}

1. Fitzmaurice, C.; Akinyemiju, T.F.; Al Lami, F.H.; Alam, T.; Alizadeh-Navaei, R.; Allen, C.; Alsharif, U.; Alvis-Guzman, N.; Amini, E.; Anderson, B.O.; et al. Global, Regional, and National Cancer Incidence, Mortality, Years of Life Lost, Years Lived With Disability, and Disability-Adjusted Life-Years for 29 Cancer Groups, 1990 to 2016: A Systematic Analysis for the Global Burden of Disease Study. JAMA Oncol. 2018, 4, 1553-1568. [CrossRef] [PubMed]

2. Siegel, R.L.; Miller, K.D.; Jemal, A. Cancer statistics, 2018. CA Cancer J. Clin. 2018, 68, 7-30. [CrossRef] [PubMed]

3. Watanabe, M.; Nakayama, T.; Shiraishi, T.; Stemmermann, G.N.; Yatani, R. Comparative studies of prostate cancer in Japan versus the United States. A review. Urol. Oncol. 2000, 5, 274-283. [CrossRef]

4. Breslow, N.; Chan, C.W.; Dhom, G.; Drury, R.A.; Franks, L.M.; Gellei, B.; Lee, Y.S.; Lundberg, S.; Sparke, B.; Sternby, N.H.; et al. Latent carcinoma of prostate at autopsy in seven areas. The International Agency for Research on Cancer, Lyons, France. Int. J. Cancer 1977, 20, 680-688. [CrossRef] [PubMed]

5. Shimizu, H.; Ross, R.K.; Bernstein, L.; Yatani, R.; Henderson, B.E.; Mack, T.M. Cancers of the prostate and breast among Japanese and white immigrants in Los Angeles County. Br. J. Cancer 1991, 63, 963-966. [CrossRef] [PubMed]

6. Kimura, T.; Egawa, S. Epidemiology of prostate cancer in Asian countries. Int. J. Urol. 2018, 25, $524-531$. [CrossRef]

7. Ornish, D.; Weidner, G.; Fair, W.R.; Marlin, R.; Pettengill, E.B.; Raisin, C.J.; Dunn-Emke, S.; Crutchfield, L.; Jacobs, F.N.; Barnard, R.J.; et al. Intensive lifestyle changes may affect the progression of prostate cancer. J. Urol. 2005, 174, 1065-1069; discussion 1069-1070. [CrossRef] [PubMed]

8. Allott, E.H.; Masko, E.M.; Freedland, S.J. Obesity and prostate cancer: weighing the evidence. Eur. Urol. 2013, 63, 800-809. [CrossRef]

9. Venkateswaran, V.; Klotz, L.H. Diet and prostate cancer: mechanisms of action and implications for chemoprevention. Nat. Rev. Urol. 2010, 7, 442-453. [CrossRef]

10. Lin, P.H.; Aronson, W.; Freedland, S.J. An update of research evidence on nutrition and prostate cancer. Urol. Oncol. 2017. [CrossRef]

11. Wang, Y.; Corr, J.G.; Thaler, H.T.; Tao, Y.; Fair, W.R.; Heston, W.D. Decreased growth of established human prostate LNCaP tumors in nude mice fed a low-fat diet. J. Natl. Cancer Inst. 1995, 87, 1456-1462. [CrossRef]

12. Connolly, J.M.; Coleman, M.; Rose, D.P. Effects of dietary fatty acids on DU145 human prostate cancer cell growth in athymic nude mice. Nutri. Cancer 1997, 29, 114-119. [CrossRef]

13. Ngo, T.H.; Barnard, R.J.; Tymchuk, C.N.; Cohen, P.; Aronson, W.J. Effect of diet and exercise on serum insulin, IGF-I, and IGFBP-1 levels and growth of LNCaP cells in vitro (United States). Cancer Causes Control. 2002, 13, 929-935. [CrossRef] [PubMed]

14. Barnard, R.J.; Ngo, T.H.; Leung, P.S.; Aronson, W.J.; Golding, L.A. A low-fat diet and/or strenuous exercise alters the IGF axis in vivo and reduces prostate tumor cell growth in vitro. Prostate 2003, 56, $201-206$. [CrossRef]

15. Ngo, T.H.; Barnard, R.J.; Cohen, P.; Freedland, S.; Tran, C.; de Gregorio, F.; Elshimali, Y.I.; Heber, D.; Aronson, W.J. Effect of isocaloric low-fat diet on human LAPC-4 prostate cancer xenografts in severe combined immunodeficient mice and the insulin-like growth factor axis. Clin. Cancer Res. 2003, 9, $2734-2743$.

16. Narita, S.; Tsuchiya, N.; Saito, M.; Inoue, T.; Kumazawa, T.; Yuasa, T.; Nakamura, A.; Habuchi, T. Candidate genes involved in enhanced growth of human prostate cancer under high fat feeding identified by microarray analysis. Prostate 2008, 68, 321-335. [CrossRef]

17. Venkateswaran, V.; Haddad, A.Q.; Fleshner, N.E.; Fan, R.; Sugar, L.M.; Nam, R.; Klotz, L.H.; Pollak, M. Association of diet-induced hyperinsulinemia with accelerated growth of prostate cancer (LNCaP) xenografts. J. Natl. Cancer Inst. 2007, 99, 1793-1800. [CrossRef] [PubMed]

18. Berquin, I.M.; Min, Y.; Wu, R.; Wu, J.; Perry, D.; Cline, J.M.; Thomas, M.J.; Thornburg, T.; Kulik, G.; Smith, A.; et al. Modulation of prostate cancer genetic risk by omega-3 and omega-6 fatty acids. J. Clin. Invest. 2007, 117, 1866-1875. [CrossRef]

19. Kobayashi, N.; Barnard, R.J.; Said, J.; Hong-Gonzalez, J.; Corman, D.M.; Ku, M.; Doan, N.B.; Gui, D.; Elashoff, D.; Cohen, P.; et al. Effect of low-fat diet on development of prostate cancer and Akt phosphorylation in the Hi-Myc transgenic mouse model. Cancer Res. 2008, 68, 3066-3073. [CrossRef] 
20. Freedland, S.J.; Mavropoulos, J.; Wang, A.; Darshan, M.; Demark-Wahnefried, W.; Aronson, W.J.; Cohen, P.; Hwang, D.; Peterson, B.; Fields, T.; et al. Carbohydrate restriction, prostate cancer growth, and the insulin-like growth factor axis. Prostate 2008, 68, 11-19. [CrossRef]

21. Mavropoulos, J.C.; Buschemeyer, W.C., 3rd; Tewari, A.K.; Rokhfeld, D.; Pollak, M.; Zhao, Y.; Febbo, P.G.; Cohen, P.; Hwang, D.; Devi, G.; et al. The effects of varying dietary carbohydrate and fat content on survival in a murine LNCaP prostate cancer xenograft model. Cancer Prev. Res. 2009, 2, 557-565. [CrossRef]

22. Tamura, K.; Makino, A.; Hullin-Matsuda, F.; Kobayashi, T.; Furihata, M.; Chung, S.; Ashida, S.; Miki, T.; Fujioka, T.; Shuin, T.; et al. Novel lipogenic enzyme ELOVL7 is involved in prostate cancer growth through saturated long-chain fatty acid metabolism. Cancer Res. 2009, 69, 8133-8140. [CrossRef]

23. Kalaany, N.Y.; Sabatini, D.M. Tumours with PI3K activation are resistant to dietary restriction. Nature 2009, 458, 725-731. [CrossRef]

24. Buschemeyer, W.C., 3rd; Klink, J.C.; Mavropoulos, J.C.; Poulton, S.H.; Demark-Wahnefried, W.; Hursting, S.D.; Cohen, P.; Hwang, D.; Johnson, T.L.; Freedland, S.J. Effect of intermittent fasting with or without caloric restriction on prostate cancer growth and survival in SCID mice. Prostate 2010, 70, 1037-1043. [CrossRef]

25. Llaverias, G.; Danilo, C.; Wang, Y.; Witkiewicz, A.K.; Daumer, K.; Lisanti, M.P.; Frank, P.G. A Western-type diet accelerates tumor progression in an autochthonous mouse model of prostate cancer. Am. J. Pathol. 2010, 177, 3180-3191. [CrossRef]

26. Lloyd, J.C.; Antonelli, J.A.; Phillips, T.E.; Masko, E.M.; Thomas, J.A.; Poulton, S.H.; Pollak, M.; Freedland, S.J. Effect of isocaloric low fat diet on prostate cancer xenograft progression in a hormone deprivation model. J. Urol. 2010, 183, 1619-1624. [CrossRef]

27. Aronson, W.J.; Barnard, R.J.; Freedland, S.J.; Henning, S.; Elashoff, D.; Jardack, P.M.; Cohen, P.; Heber, D.; Kobayashi, N. Growth inhibitory effect of low fat diet on prostate cancer cells: results of a prospective, randomized dietary intervention trial in men with prostate cancer. J. Urol. 2010, 183, 345-350. [CrossRef]

28. Masko, E.M.; Thomas, J.A., 2nd; Antonelli, J.A.; Lloyd, J.C.; Phillips, T.E.; Poulton, S.H.; Dewhirst, M.W.; Pizzo, S.V.; Freedland, S.J. Low-carbohydrate diets and prostate cancer: How low is "low enough"? Cancer Prev. Res. 2010, 3, 1124-1131. [CrossRef]

29. Akinsete, J.A.; Ion, G.; Witte, T.R.; Hardman, W.E. Consumption of high omega-3 fatty acid diet suppressed prostate tumorigenesis in C3(1) Tag mice. Carcinogenesis 2012, 33, 140-148. [CrossRef]

30. Mao, G.E.; Harris, D.M.; Moro, A.; Heber, D.; Roy-Burman, P.; Zhang, Z.F.; Rao, J. A joint effect of new Western diet and retinoid $X$ receptor alpha prostate-specific knockout with development of high-grade prostatic intraepithelial neoplasia in mice-A preliminary study. Prostate 2012, 72, 1052-1059. [CrossRef]

31. Bonorden, M.J.; Grossmann, M.E.; Ewing, S.A.; Rogozina, O.P.; Ray, A.; Nkhata, K.J.; Liao, D.J.; Grande, J.P.; Cleary, M.P. Growth and Progression of TRAMP Prostate Tumors in Relationship to Diet and Obesity. Prostate Cancer 2012, 2012, 543970. [CrossRef]

32. Konijeti, R.; Koyama, S.; Gray, A.; Barnard, R.J.; Said, J.W.; Castor, B.; Elashoff, D.; Wan, J.; Beltran, P.J.; Calzone, F.J.; et al. Effect of a low-fat diet combined with IGF-1 receptor blockade on 22Rv1 prostate cancer xenografts. Mol. Cancer Ther. 2012, 11, 1539-1546. [CrossRef]

33. Huang, M.; Narita, S.; Numakura, K.; Tsuruta, H.; Saito, M.; Inoue, T.; Horikawa, Y.; Tsuchiya, N.; Habuchi, T. A high-fat diet enhances proliferation of prostate cancer cells and activates MCP-1/CCR2 signaling. Prostate 2012, 72, 1779-1788. [CrossRef]

34. Wang, S.; Wu, J.; Suburu, J.; Gu, Z.; Cai, J.; Axanova, L.S.; Cramer, S.D.; Thomas, M.J.; Perry, D.L.; Edwards, I.J.; et al. Effect of dietary polyunsaturated fatty acids on castration-resistant Pten-null prostate cancer. Carcinogenesis. 2012, 33, 404-412. [CrossRef]

35. Vandersluis, A.D.; Venier, N.A.; Colquhoun, A.J.; Sugar, L.; Pollak, M.; Kiss, A.; Fleshner, N.E.; Klotz, L.H.; Venkateswaran, V. Exercise does not counteract the effects of a "westernized" diet on prostate cancer xenografts. Prostate 2013, 73, 1223-1232. [CrossRef]

36. Pommier, A.J.; Dufour, J.; Alves, G.; Viennois, E.; De Boussac, H.; Trousson, A.; Volle, D.H.; Caira, F.; Val, P.; Arnaud, P.; et al. Liver $\mathrm{x}$ receptors protect from development of prostatic intra-epithelial neoplasia in mice. PLoS Genet. 2013, 9, e1003483. [CrossRef]

37. Huang, M.; Narita, S.; Inoue, T.; Tsuchiya, N.; Satoh, S.; Nanjo, H.; Sasaki, T.; Habuchi, T. Diet-induced macrophage inhibitory cytokine 1 promotes prostate cancer progression. Endocr. Relat. Cancer 2014, 21, 39-50. [CrossRef] 
38. Moiola, C.P.; De Luca, P.; Zalazar, F.; Cotignola, J.; Rodriguez-Segui, S.A.; Gardner, K.; Meiss, R.; Vallecorsa, P.; Pignataro, O.; Mazza, O.; et al. Prostate tumor growth is impaired by CtBP1 depletion in high-fat diet-fed mice. Clin. Cancer Res. 2014, 20, 4086-4095. [CrossRef]

39. Chang, S.N.; Han, J.; Abdelkader, T.S.; Kim, T.H.; Lee, J.M.; Song, J.; Kim, K.S.; Park, J.H. High animal fat intake enhances prostate cancer progression and reduces glutathione peroxidase 3 expression in early stages of TRAMP mice. Prostate 2014, 74, 1266-1277. [CrossRef]

40. Liu, J.; Ramakrishnan, S.K.; Khuder, S.S.; Kaw, M.K.; Muturi, H.T.; Lester, S.G.; Lee, S.J.; Fedorova, L.V.; Kim, A.J.; Mohamed, I.E.; et al. High-calorie diet exacerbates prostate neoplasia in mice with haploinsufficiency of Pten tumor suppressor gene. Mol. Metab. 2015, 4, 186-198. [CrossRef]

41. Cho, H.J.; Kwon, G.T.; Park, H.; Song, H.; Lee, K.W.; Kim, J.I.; Park, J.H. A high-fat diet containing lard accelerates prostate cancer progression and reduces survival rate in mice: Possible contribution of adipose tissue-derived cytokines. Nutrients 2015, 7, 2539-2561. [CrossRef]

42. Xu, H.; Hu, M.B.; Bai, P.D.; Zhu, W.H.; Liu, S.H.; Hou, J.Y.; Xiong, Z.Q.; Ding, Q.; Jiang, H.W. Proinflammatory cytokines in prostate cancer development and progression promoted by high-fat diet. BioMed Res. Int. 2015, 2015, 249741. [CrossRef]

43. Xu, H.; Jiang, H.W.; Ding, Q. Insulin-Like growth factor 1 related pathways and high-fat diet promotion of transgenic adenocarcinoma mouse prostate (TRAMP) cancer progression. Actas Urol. Esp. 2015, 39, 161-168. [CrossRef]

44. Lo, J.C.; Clark, A.K.; Ascui, N.; Frydenberg, M.; Risbridger, G.P.; Taylor, R.A.; Watt, M.J. Obesity does not promote tumorigenesis of localized patient-derived prostate cancer xenografts. Oncotarget. 2016, 7, 47650-47662. [CrossRef]

45. Liang, P.; Henning, S.M.; Schokrpur, S.; Wu, L.; Doan, N.; Said, J.; Grogan, T.; Elashoff, D.; Cohen, P.; Aronson, W.J. Effect of Dietary Omega-3 Fatty Acids on Tumor-Associated Macrophages and Prostate Cancer Progression. Prostate 2016, 76, 1293-1302. [CrossRef]

46. Huang, M.; Koizumi, A.; Narita, S.; Inoue, T.; Tsuchiya, N.; Nakanishi, H.; Numakura, K.; Tsuruta, H.; Saito, M.; Satoh, S.; et al. Diet-induced alteration of fatty acid synthase in prostate cancer progression. Oncogenesis 2016, 5, e195. [CrossRef]

47. Labbe, D.P.; Uetani, N.; Vinette, V.; Lessard, L.; Aubry, I.; Migon, E.; Sirois, J.; Haigh, J.J.; Begin, L.R.; Trotman, L.C.; et al. PTP1B Deficiency Enables the Ability of a High-Fat Diet to Drive the Invasive Character of PTEN-Deficient Prostate Cancers. Cancer Res. 2016, 76, 3130-3135. [CrossRef]

48. Kwon, O.J.; Zhang, B.; Zhang, L.; Xin, L. High fat diet promotes prostatic basal-to-luminal differentiation and accelerates initiation of prostate epithelial hyperplasia originated from basal cells. Stem Cell Res. 2016, 16, 682-691. [CrossRef]

49. Zhang, T.; Tseng, C.; Zhang, Y.; Sirin, O.; Corn, P.G.; Li-Ning-Tapia, E.M.; Troncoso, P.; Davis, J.; Pettaway, C.; Ward, J.; et al. CXCL1 mediates obesity-associated adipose stromal cell trafficking and function in the tumour microenvironment. Nat. Commun. 2016, 7, 11674. [CrossRef]

50. Chang, C.C.; Chen, C.Y.; Wen, H.C.; Huang, C.Y.; Hung, M.S.; Lu, H.C.; Chen, W.L.; Chang, C.H. Caveolin-1 Secreted from Adipose Tissues and Adipocytes Functions as an Adipogenesis Enhancer. Obesity 2017, 25, 1932-1940. [CrossRef]

51. Kim, S.; Yang, X.; Li, Q.; Wu, M.; Costyn, L.; Beharry, Z.; Bartlett, M.G.; Cai, H. Myristoylation of Src kinase mediates Src-induced and high-fat diet-accelerated prostate tumor progression in mice. J. Biol. Chem. 2017, 292, 18422-18433. [CrossRef]

52. Nara, T.; Narita, S.; Mingguo, H.; Yoshioka, T.; Koizumi, A.; Numakura, K.; Tsuruta, H.; Maeno, A.; Saito, M.; Inoue, T.; et al. Altered miRNA expression in high-fat diet-induced prostate cancer progression. Carcinogenesis 2016, 37, 1129-1137. [CrossRef]

53. Huang, M.; Narita, S.; Inoue, T.; Koizumi, A.; Saito, M.; Tsuruta, H.; Numakura, K.; Satoh, S.; Nanjo, H.; Sasaki, T.; et al. Fatty acid binding protein 4 enhances prostate cancer progression by upregulating matrix metalloproteinases and stromal cell cytokine production. Oncotarget 2017, 8, 111780-111794. [CrossRef]

54. Hayashi, T.; Fujita, K.; Nojima, S.; Hayashi, Y.; Nakano, K.; Ishizuya, Y.; Wang, C.; Yamamoto, Y.; Kinouchi, T.; Matsuzaki, K.; et al. High-Fat Diet-Induced Inflammation Accelerates Prostate Cancer Growth via IL6 Signaling. Clin. Cancer Res. 2018, 24, 4309-4318. [CrossRef] 
55. Massillo, C.; Dalton, G.N.; Porretti, J.; Scalise, G.D.; Farre, P.L.; Piccioni, F.; Secchiari, F.; Pascuali, N.; Clyne, C.; Gardner, K.; et al. CTBP1/CYP19A1/estradiol axis together with adipose tissue impacts over prostate cancer growth associated to metabolic syndrome. Int. J. Cancer 2019, 144, 1115-1127. [CrossRef]

56. Chen, M.; Zhang, J.; Sampieri, K.; Clohessy, J.G.; Mendez, L.; Gonzalez-Billalabeitia, E.; Liu, X.S.; Lee, Y.R.; Fung, J.; Katon, J.M.; et al. An aberrant SREBP-dependent lipogenic program promotes metastatic prostate cancer. Nat. Genet. 2018, 50, 206-218. [CrossRef]

57. Hu, M.B.; Xu, H.; Zhu, W.H.; Bai, P.D.; Hu, J.M.; Yang, T.; Jiang, H.W.; Ding, Q. High-fat diet-induced adipokine and cytokine alterations promote the progression of prostate cancer in vivo and in vitro. Oncol. Lett. 2018, 15, 1607-1615. [CrossRef]

58. Ngo, T.H.; Barnard, R.J.; Anton, T.; Tran, C.; Elashoff, D.; Heber, D.; Freedland, S.J.; Aronson, W.J. Effect of isocaloric low-fat diet on prostate cancer xenograft progression to androgen independence. Cancer Res. 2004, 64, 1252-1254. [CrossRef]

59. Budhu, S.; Wolchok, J.; Merghoub, T. The importance of animal models in tumor immunity and immunotherapy. Curr. Opin. Genet. Dev. 2014, 24, 46-51. [CrossRef]

60. Gingrich, J.R.; Barrios, R.J.; Morton, R.A.; Boyce, B.F.; DeMayo, F.J.; Finegold, M.J.; Angelopoulou, R.; Rosen, J.M.; Greenberg, N.M. Metastatic prostate cancer in a transgenic mouse. Cancer Res. 1996, 56, 4096-4102.

61. Irshad, S.; Abate-Shen, C. Modeling prostate cancer in mice: something old, something new, something premalignant, something metastatic. Cancer Metastasis Rev. 2013, 32, 109-122. [CrossRef]

62. Hu, M.B.; Hu, J.M.; Jiang, L.R.; Yang, T.; Zhu, W.H.; Hu, Y.; Wu, X.B.; Jiang, H.W.; Ding, Q. Differential expressions of integrin-linked kinase, beta-parvin and cofilin 1 in high-fat diet induced prostate cancer progression in a transgenic mouse model. Oncol. Lett. 2018, 16, 4945-4952. [CrossRef]

63. Ellwood-Yen, K.; Graeber, T.G.; Wongvipat, J.; Iruela-Arispe, M.L.; Zhang, J.; Matusik, R.; Thomas, G.V.; Sawyers, C.L. Myc-driven murine prostate cancer shares molecular features with human prostate tumors. Cancer Cell 2003, 4, 223-238. [CrossRef]

64. Cunningham, D.; You, Z. In vitro and in vivo model systems used in prostate cancer research. J. Biol. Methods 2015, 2. [CrossRef]

65. Shappell, S.B.; Thomas, G.V.; Roberts, R.L.; Herbert, R.; Ittmann, M.M.; Rubin, M.A.; Humphrey, P.A.; Sundberg, J.P.; Rozengurt, N.; Barrios, R.; et al. Prostate pathology of genetically engineered mice: Definitions and classification. The consensus report from the Bar Harbor meeting of the Mouse Models of Human Cancer Consortium Prostate Pathology Committee. Cancer Res. 2004, 64, 2270-2305. [CrossRef]

66. Buettner, R.; Scholmerich, J.; Bollheimer, L.C. High-fat diets: modeling the metabolic disorders of human obesity in rodents. Obesity 2007, 15, 798-808. [CrossRef]

67. Khodadadi, S.; Sobhani, N.; Mirshekar, S.; Ghiasvand, R.; Pourmasoumi, M.; Miraghajani, M.; Dehsoukhteh, S.S. Tumor Cells Growth and Survival Time with the Ketogenic Diet in Animal Models: A Systematic Review. Int. J. Pre. Med. 2017, 8, 35. [CrossRef]

68. Di Sebastiano, K.M.; Mourtzakis, M. The role of dietary fat throughout the prostate cancer trajectory. Nutrients 2014, 6, 6095-6109. [CrossRef]

69. Heber, D.; Kritchevsky, D. Dietary Fats, Lipids, Hormones, and Tumorigenesis. Available online: https: //www.springer.com/la/book/9780306453175 (accessed on 30 April 2019).

70. Hariri, N.; Thibault, L. High-fat diet-induced obesity in animal models. Nutrition Res. Rev. 2010, 23, $270-299$. [CrossRef]

71. Hilvo, M.; Denkert, C.; Lehtinen, L.; Muller, B.; Brockmoller, S.; Seppanen-Laakso, T.; Budczies, J.; Bucher, E.; Yetukuri, L.; Castillo, S.; et al. Novel theranostic opportunities offered by characterization of altered membrane lipid metabolism in breast cancer progression. Cancer Res. 2011, 71, 3236-3245. [CrossRef]

72. Guo, S.; Wang, Y.; Zhou, D.; Li, Z. Significantly increased monounsaturated lipids relative to polyunsaturated lipids in six types of cancer microenvironment are observed by mass spectrometry imaging. Sci. Rep. 2014, 4, 5959. [CrossRef]

73. Othman, R. Dietary lipids and cancer. Libyan J. Med. 2007, 2, 180-184. [CrossRef]

74. Simopoulos, A.P. Evolutionary aspects of diet, the omega-6/omega-3 ratio and genetic variation: nutritional implications for chronic diseases. Biomed. Pharmacother. 2006, 60, 502-507. [CrossRef]

75. Berquin, I.M.; Edwards, I.J.; Kridel, S.J.; Chen, Y.Q. Polyunsaturated fatty acid metabolism in prostate cancer. Cancer Metastasis Rev. 2011, 30, 295-309. [CrossRef] 
76. Spencer, L.; Mann, C.; Metcalfe, M.; Webb, M.; Pollard, C.; Spencer, D.; Berry, D.; Steward, W.; Dennison, A. The effect of omega-3 FAs on tumour angiogenesis and their therapeutic potential. Eur. J. Cancer 2009, 45, 2077-2086. [CrossRef]

77. Buettner, R.; Parhofer, K.G.; Woenckhaus, M.; Wrede, C.E.; Kunz-Schughart, L.A.; Scholmerich, J.; Bollheimer, L.C. Defining high-fat-diet rat models: Metabolic and molecular effects of different fat types. J. Mol. Endocrinol. 2006, 36, 485-501. [CrossRef]

78. Allott, E.H.; Masko, E.M.; Freedland, A.R.; Macias, E.; Pelton, K.; Solomon, K.R.; Mostaghel, E.A.; Thomas, G.V.; Pizzo, S.V.; Freeman, M.R.; et al. Serum cholesterol levels and tumor growth in a PTEN-null transgenic mouse model of prostate cancer. Prostate Cancer Prostatic Dis. 2018, 21, 196-203. [CrossRef]

79. Babcook, M.A.; Joshi, A.; Montellano, J.A.; Shankar, E.; Gupta, S. Statin Use in Prostate Cancer: An Update. Nutr. Metab. Insights 2016, 9, 43-50. [CrossRef]

80. Murtola, T.J.; Tammela, T.L.; Maattanen, L.; Huhtala, H.; Platz, E.A.; Ala-Opas, M.; Stenman, U.H.; Auvinen, A. Prostate cancer and PSA among statin users in the Finnish prostate cancer screening trial. Int. J. Cancer 2010, 127, 1650-1659. [CrossRef]

81. Roberts, D.L.; Dive, C.; Renehan, A.G. Biological mechanisms linking obesity and cancer risk: New perspectives. Annu. Rev. Med. 2010, 61, 301-316. [CrossRef]

82. Ma, J.; Li, H.; Giovannucci, E.; Mucci, L.; Qiu, W.; Nguyen, P.L.; Gaziano, J.M.; Pollak, M.; Stampfer, M.J. Prediagnostic body-mass index, plasma C-peptide concentration, and prostate cancer-specific mortality in men with prostate cancer: A long-term survival analysis. Lancet. Oncol. 2008, 9, 1039-1047. [CrossRef]

83. Poloz, Y.; Stambolic, V. Obesity and cancer, a case for insulin signaling. Cell Death Dis. 2015, 6, e2037. [CrossRef]

84. Lin, J.; Yang, R.; Tarr, P.T.; Wu, P.H.; Handschin, C.; Li, S.; Yang, W.; Pei, L.; Uldry, M.; Tontonoz, P.; et al. Hyperlipidemic effects of dietary saturated fats mediated through PGC-1beta coactivation of SREBP. Cell 2005, 120, 261-273. [CrossRef]

85. De Marzo, A.M.; Platz, E.A.; Sutcliffe, S.; Xu, J.; Gronberg, H.; Drake, C.G.; Nakai, Y.; Isaacs, W.B.; Nelson, W.G. Inflammation in prostate carcinogenesis. Nat. Rev. Cancer 2007, 7, 256-269. [CrossRef]

86. Lumeng, C.N.; Deyoung, S.M.; Bodzin, J.L.; Saltiel, A.R. Increased inflammatory properties of adipose tissue macrophages recruited during diet-induced obesity. Diabetes 2007, 56, 16-23. [CrossRef]

87. Huang, M.; Narita, S.; Tsuchiya, N.; Ma, Z.; Numakura, K.; Obara, T.; Tsuruta, H.; Saito, M.; Inoue, T.; Horikawa, Y.; et al. Overexpression of Fn14 promotes androgen-independent prostate cancer progression through MMP-9 and correlates with poor treatment outcome. Carcinogenesis. 2011, 32, 1589-1596. [CrossRef]

88. Di Zazzo, E.; Polito, R.; Bartollino, S.; Nigro, E.; Porcile, C.; Bianco, A.; Daniele, A.; Moncharmont, B. Adiponectin as Link Factor between Adipose Tissue and Cancer. Int. J. Mol. Sci. 2019, 20, 839. [CrossRef]

89. Di Zazzo, E.; Galasso, G.; Giovannelli, P.; Di Donato, M.; Castoria, G. Estrogens and Their Receptors in Prostate Cancer: Therapeutic Implications. Front. Oncol. 2018, 8, 2. [CrossRef]

90. Allen, N.E.; Key, T.J. The effects of diet on circulating sex hormone levels in men. Nutr. Res. Rev. 2000, 13, 159-184. [CrossRef]

(C) 2019 by the authors. Licensee MDPI, Basel, Switzerland. This article is an open access article distributed under the terms and conditions of the Creative Commons Attribution (CC BY) license (http://creativecommons.org/licenses/by/4.0/). 